\title{
Archaeological Prospection of Coastal and Submerged Settlement Sites. Re-Evaluation of the Roman Site Complex of Vižula, Croatia
}

\author{
Nives Doneus \\ Igor Miholjek \\ Kristina Džin \\ Michael Doneus \\ Pavle Dugonjić \\ Hannes Schiel
}

\begin{abstract}
For many decades the villa maritima of Vižula had been considered as one of the largest of its kind in Istria, Croatia. In order to prove this theory, large-scale archaeological prospection was applied in Vižula from 2014 onwards, including geophysics (Ground Penetrating Radar) and remote sensing (Airborne Laser Scanning/Airborne Laser Bathymetry). Integrating the results of these non-invasive techniques with terrestrial and underwater surveys and excavations provided an opportunity to evaluate this architecture from a different perspective. Our research indicates that instead of a single luxurious residence, several contemporary complexes existed on Vižula, namely two villae maritimae and two villae rusticae. Furthermore, the results show that the combined methodology is able to integrate detail and context into an interpretative coherent model of a landscape going far beyond the analytical capabilities of each individual method.
\end{abstract}

\section{Keywords}

Mediterranean, Roman villa maritima, archaeological prospection, ALS/ALB, GPR, underwater archaeology, integrated interpretation of prospection data.

Zusammenfassung - Archäologische Prospektion von Siedlungen im Küstenbereich. Neubewertung der römischen Architektur von Vižula, Kroatien

Viele Jahrzehnte lang galt die villa maritima von Vižula als eine der größten ihrer Art in Istrien, Kroatien. Um diese Theorie zu überprüfen, wurde seit 2014 großflächige archäologische Prospektion in die Erforschung von Vižula einbezogen, und das Gebiet mittels Geophysik (Bodenradar) und Fernerkundung (Luftbild, Airborne Laser Scanning / Airborne Laser Bathymetrie) untersucht. Die Integration der Ergebnisse dieser nicht-invasiven Techniken in die Resultate der terrestrischen und Unterwasserausgrabungen bot die Gelegenheit, diese Architektur aus einer neuen, gesamtheitlichen Perspektive zu bewerten. Unsere Forschungen deuten darauf hin, dass statt einer einzigen luxuriösen Residenz mehrere zeitgenössische Komplexe auf Vižula existierten, nämlich zwei villae maritimae und zwei villae rusticae. Darüber hinaus zeigen die Ergebnisse, dass eine kombinierte Interpretation von integrierter Prospektion und Ausgrabungen Resultate ermöglicht, die weit über die analytischen Möglichkeiten der einzelnen Methoden hinausgehen.

\section{Schlüsselbegriffe}

Mittelmeer, römische villa maritima, archäologische Prospektion, ALS/ALB, GPR, Unterwasserarchäologie, integrierte Interpretation von Prospektionsdaten.

\section{Introduction}

Past settlement sites sometimes offer themselves to the naked eye of the researcher, as architectural remains are still visible and give an impression of fortifications, antique buildings, funeral monuments or temples. The same is true for the socalled villae maritimae - large, luxurious country residences emerging during the $2^{\text {nd }}$ century $\mathrm{BC}$ on the Campanian coast in Italy. ${ }^{1}$ Slightly later, these representative country estates are also found on the Croatian coast, mainly situated on the west side of Istria. ${ }^{2}$ One of them, the so-called villa mariti$m a$ of Vižula, is the subject of this paper.

Archaeological research into such large monuments is confronted with very specific problems. A villa maritima

\footnotetext{
1 D'Arms 1970.

2 The most recent list of villae maritimae in Croatia including relevant publications can be found in Teichner, Ugarković 2012, 118-120. - See also the summary in Bowden 2018.
} 
can have a size that is - also by today's standards - of overwhelming dimensions. ${ }^{3}$ Such 'large-scale' villae can hardly be documented through excavations. Archaeological investigations therefore need to follow different approaches. Moreover, villae maritimae were built on the shore line, in an effort to integrate land and sea into their architecture. ${ }^{4}$ Due to the general rising level of the Mediterranean Sea, today those architectural features are often partly submerged. This conceals the original relationship between the architecture and the landscape and the remains of these sites are seated both in terrestrial and underwater environments. This fact is often reflected in archaeological fieldwork, where different teams of specialized researchers work separately from each other. As a result, fragmentary information makes an integrated interpretation of such monuments difficult.

The Roman remains on the peninsula of Vižula highlight this problem. The site complex is unique in its size. The extent of over 20 ha makes it difficult for archaeologists to pay attention to each and every aspect of the site and to come to a coherent interpretation of its function. As a result, it was unclear whether the documented remains represent a single large Roman complex or several smaller ones.

This paper is an attempt to re-evaluate the Roman architecture of Vižula and to present a new interpretation of its remains based on an integrated approach combining largescale archaeological prospection with the results of underwater and terrestrial excavations. After an introduction of the archaeological site of Vižula and its research history, the applied methods are presented and their results described in detail. Finally, a re-evaluation of the site is discussed both on the basis of the results obtained and considering the relationship with the past landscape.

\section{The Peninsula of Vižula}

\subsection{Geographical Setting}

The small peninsula of Vižula comprises an area of almost $24 \mathrm{ha}$. It is located on the southern tip of Istria, approximately $10 \mathrm{~km}$ south of the modern town of Pula (Fig. 1). Administratively, Vižula belongs to the small town of Medulin, which today is mainly a tourism-oriented centre. Facing the sea, Vižula overlooks Medulin Bay, which has a total length of $8 \mathrm{~km}$. The inner part of the bay, where Vižula is located, is very shallow with water depths of less than $10 \mathrm{~m}$.

The peninsula shows a naturally rising terrain that reaches its highest point in the centre with a height of about $13.5 \mathrm{~m}$ above sea level. It is connected to the mainland by a narrow $80 \mathrm{~m}$-wide land bridge called Burle. Vižula is to a

3 Compare, e.g., villae in the catalogue section of LAFON 2001.

4 As early as 1910 A. Gnirs tried to classify the villas according to their location on the Istrian coastline. large extent covered with dense vegetation in the form of shrubs and evergreen trees and is used during the warm part of the year as a recreational and bathing area.

The Roman architectural remains are preserved both on land and under water. Especially along the seashore and in the very shallow waters, remains of various settlement features are visible to the naked eye over a length of more than $1 \mathrm{~km}$ (Fig. 2). In the tidal zone the waves and currents have completely removed walls, leaving only the remains of stone foundations. In many cases, the force of the waves has also destroyed original floors down to the lowest construction layers. In particular, objects located on the southern side of Vižula, which are exposed to the stormy SE wind (croat. jugo), have suffered severe damage.

Topographically, a narrow coastal strip of the intertidal zone (with tides of c. $0.5-1 \mathrm{~m}$ ) is often accompanied by a $2 \mathrm{~m}$-high terrace. It was formed by the erosion of the coastal strip, where the natural vegetation and soils have disappeared. The exposed profile of the terrace shows its stratification and architectural remains (Fig. 2). Walking further inland, they soon disappear below the sediments or the dense Mediterranean vegetation of the higher ground. Only the areas next to a modern path, which traces the outline of the peninsula parallel to the coastline, are cleared of macchia (Fig. 3).

\subsection{Research History}

The history of Vižula is mainly reconstructed on the basis of archaeological finds, as written or graphic sources rarely refer to the region. The oldest settlement traces on the peninsula date to prehistory. A Neolithic settlement located on the north side of Vižula was partially excavated in the late $1960 s^{5}$ and published in 2004. ${ }^{6}$ Other prehistoric finds are scattered over large parts of Vižula and were also uncovered during underwater excavations in the area of the Roman pier (Object $\mathrm{F}$ in Fig. 4).?

The archaeology of the peninsula is dominated by Roman architectural remains, already mentioned in literature at the beginning of the $20^{\text {th }}$ century. ${ }^{8}$ In the mid-1990s the peninsula's terrain was systematically surveyed and Roman settlement remains were documented along the seashore over a length of approximately $1.2 \mathrm{~km} .{ }^{9}$ In order to clearly identify individual architectural elements visible on the surface, a nomenclature of the site was introduced (archaeological zones 1-6; Fig. 4). The survey was followed

\footnotetext{
5 BAČIĆ 1969.

6 Codacci 2004.

7 Unpublished underwater excavation report 2008.

8 Summarized in Giradi Jurkić 2008a, 5-8.

9 DžIN 1995.
} 


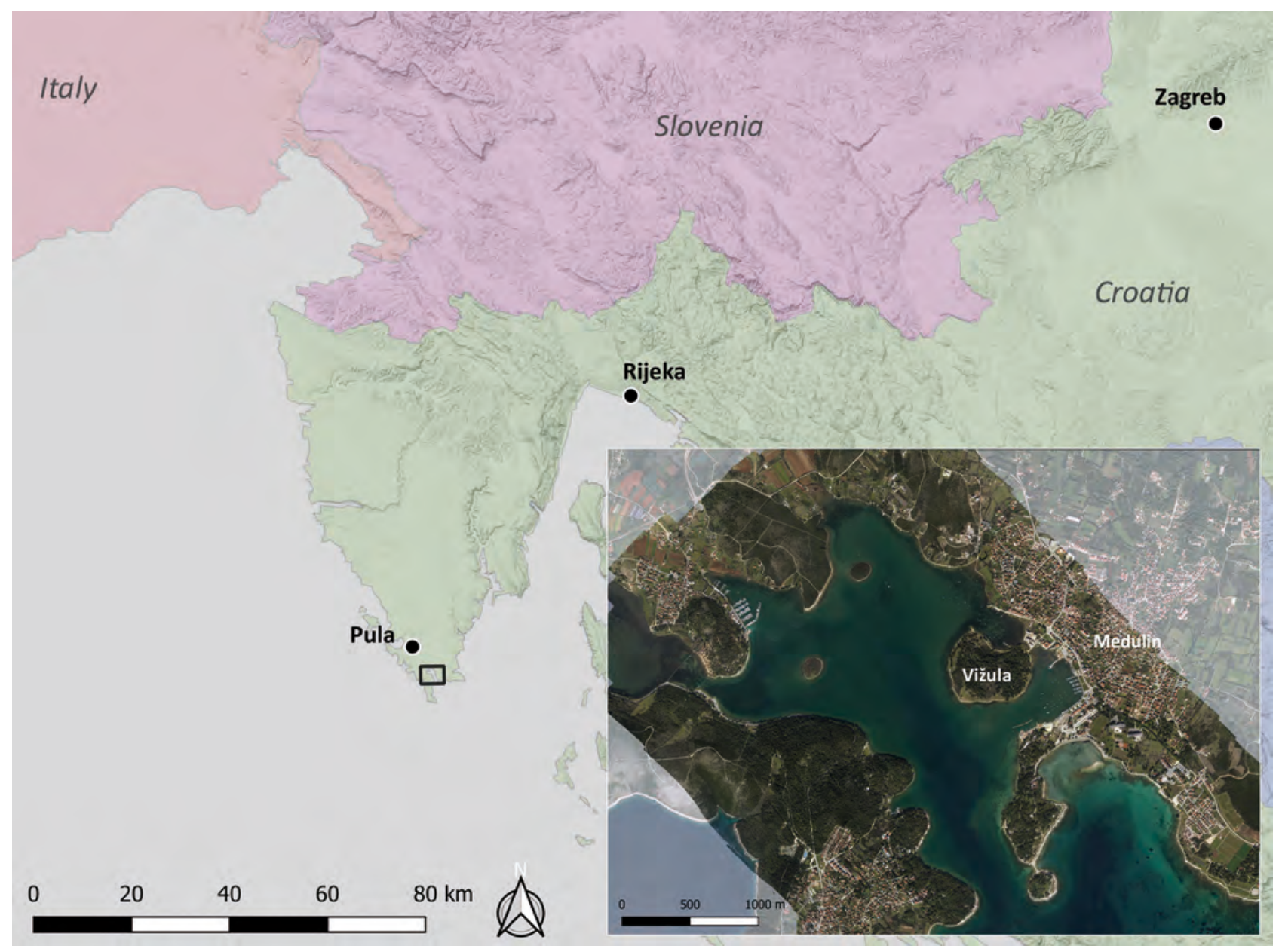

Fig. 1. Vižula is located in the south of the Istrian peninsula, next to the town of Medulin (Layout: M. Doneus, @ Orthophotograph acquired during the ALS flight mission 2018).

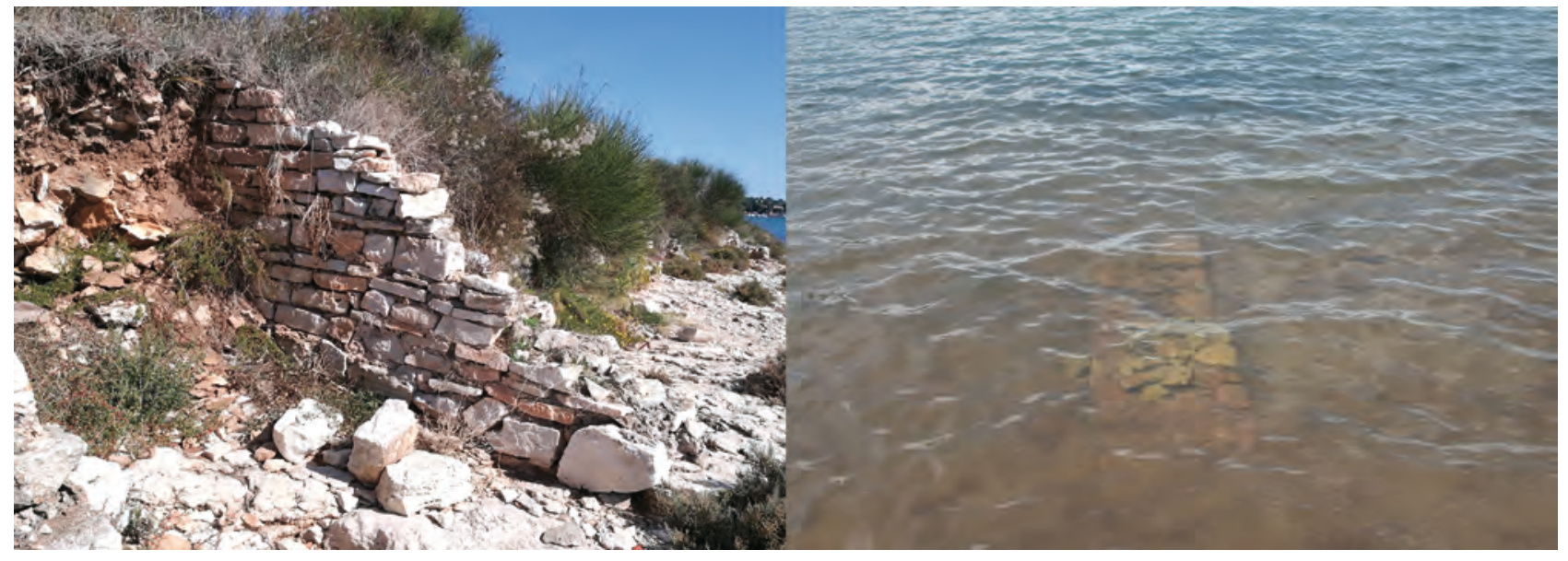

Fig. 2. Roman buildings are visible at numerous locations along the coast of Vižula (Photos: N. Doneus). 


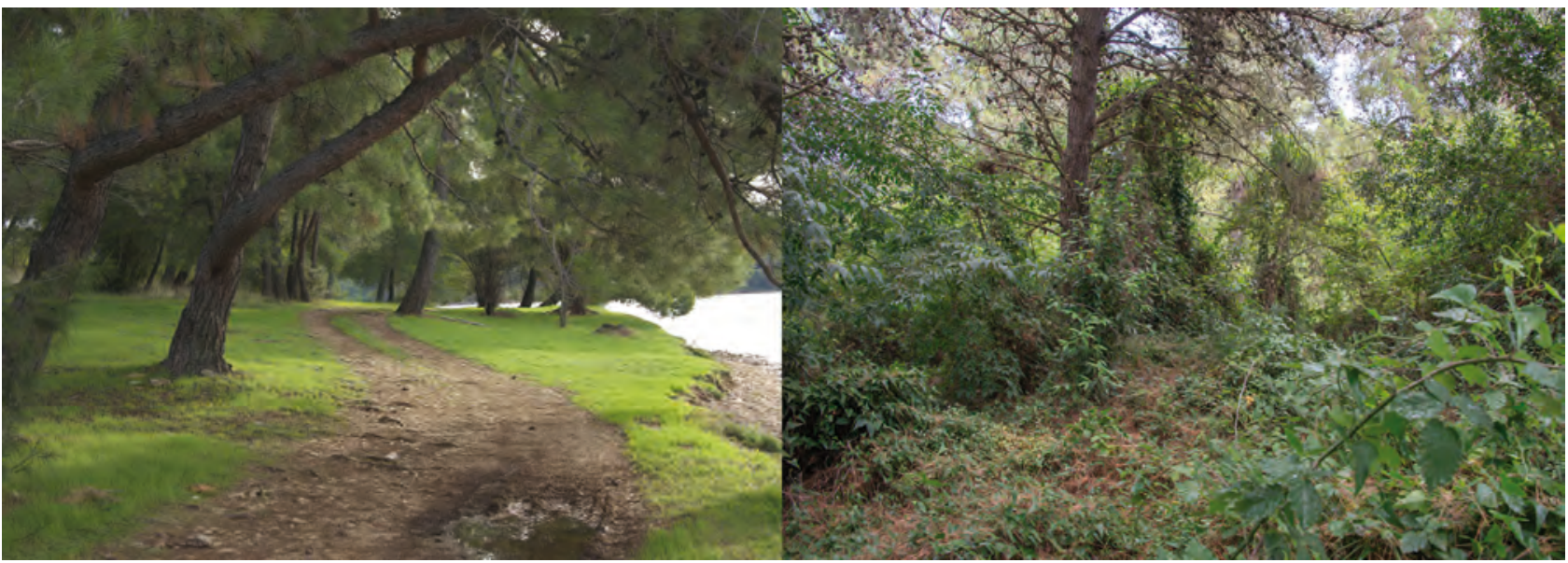

Fig. 3. Left: A modern path leads around the peninsula and is bordered by large pine trees. - Right: By contrast, the centre of the peninsula is dominated by dense vegetation (Photos: M. Doneus).

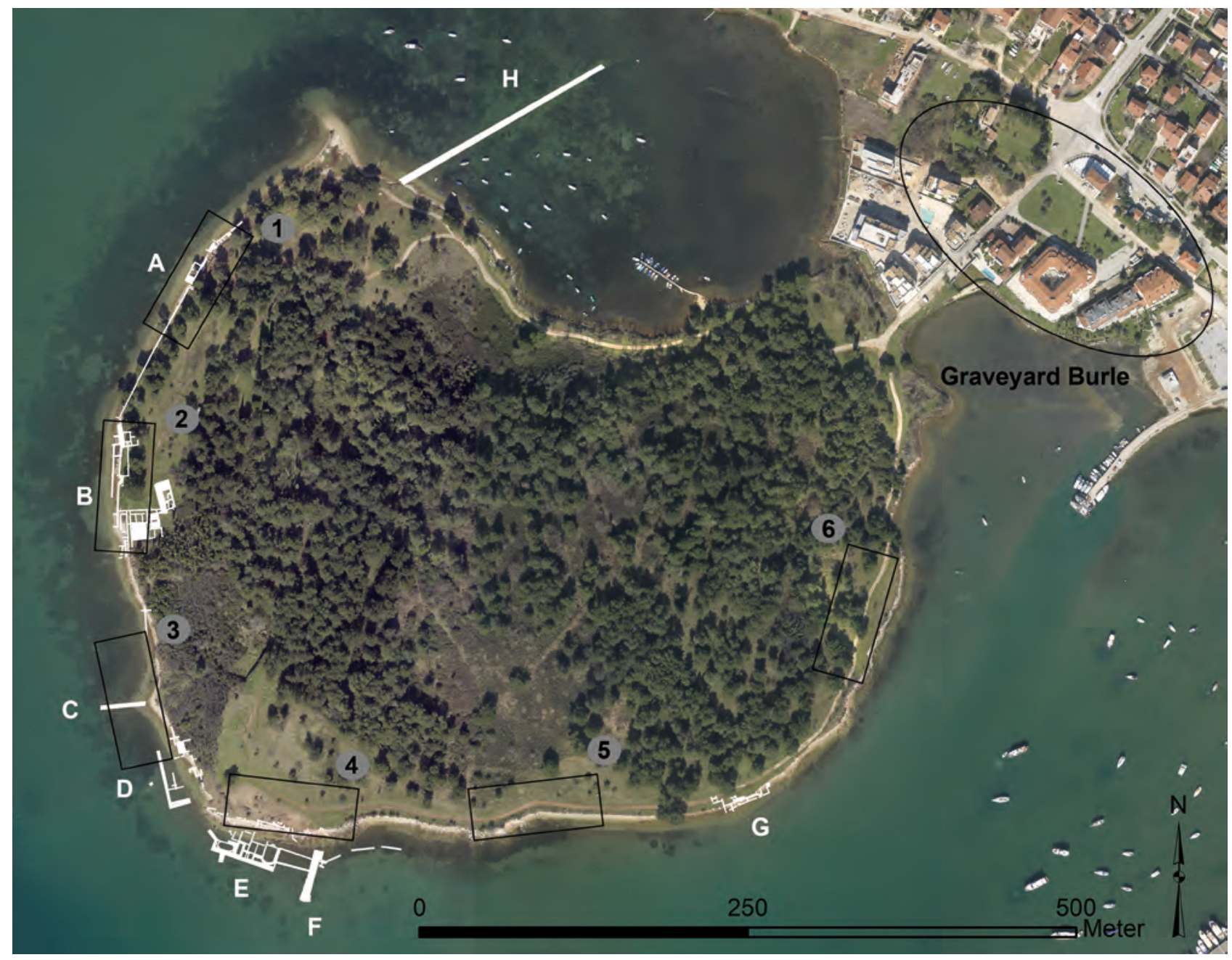

Fig. 4. Distribution of archaeological zones in Vižula. -1-6. Terrestrial zones. - A-H. Underwater objects (Graphic: N. Doneus, $\odot$ Orthophotograph acquired during the ALS flight mission 2018). 


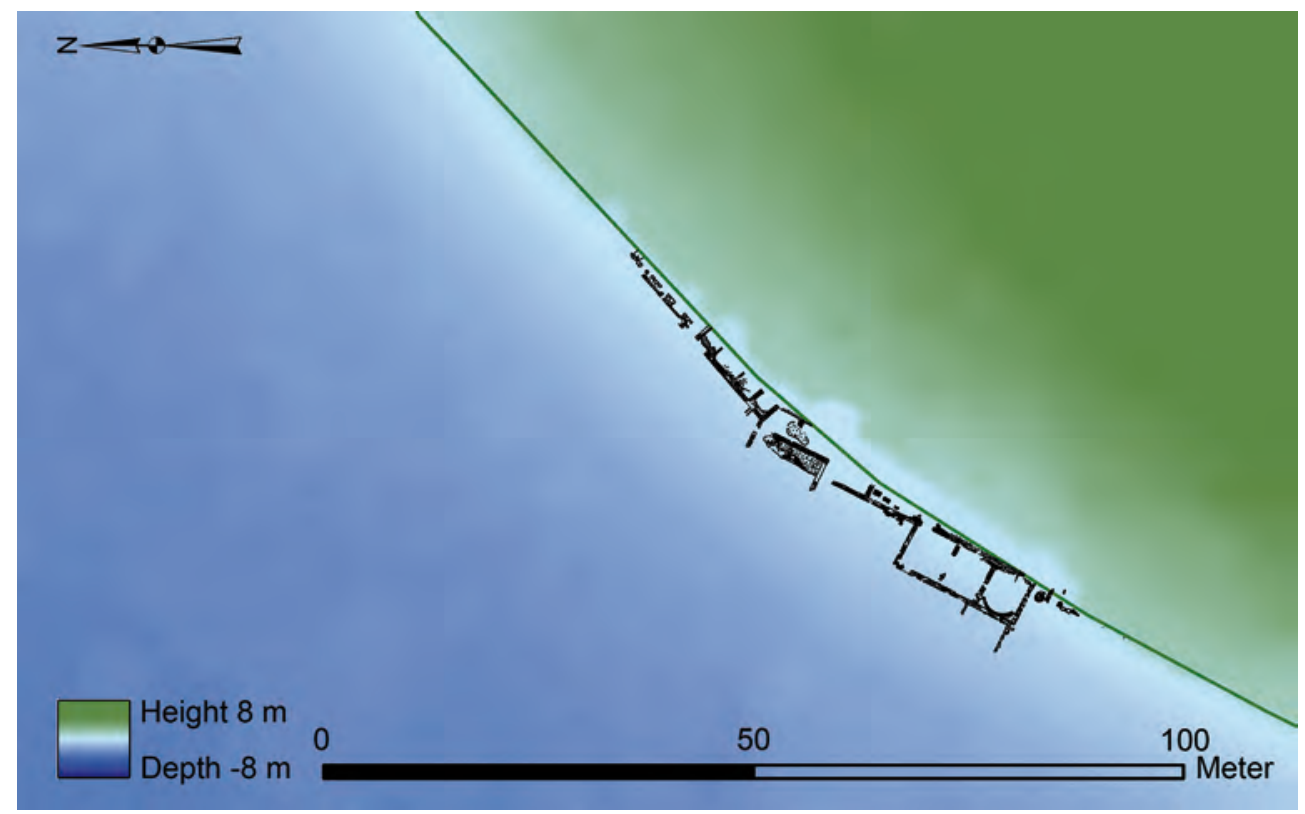

Fig. 5. Object A, state of research 2014. - The green line marks the 0 height and today's coastline (Graphic: N. Doneus).

by archaeological excavations, concentrating exclusively on zone 2, the area of the presumed main residential building (villa maritima).

First notes referring to Roman structures underwater date back to the end of the 1970s but it was not until 1995 that systematic underwater research began at Vižula. ${ }^{10} \mathrm{~A}$ different naming strategy was used during that research (objects or building complexes A-H; ${ }^{11}$ Fig. 4), since the nomenclature of terrestrial archaeological zones did not meet the needs of the underwater excavations.

Altogether, eight different objects were defined (Objects A-H), four of them settlement objects (A, B, D and E), two piers $(\mathrm{C}$ and $\mathrm{F})$ and a road $(\mathrm{H})$; while today all of the settlement features are only partly submerged, the two piers and the road are completely covered by water.

The visible remains of Object $A$ are located on the beach, in the intertidal zone (Fig. 5)..$^{12}$ Several small rooms of a building have been documented, most of them with remains of waterproof mortar, opus spicatum, floor mosaics or hypocaust heating. An interpretation as a thermal part of a small villa has been suggested. ${ }^{13}$ Finds provide a dating range from the $1^{\text {st }}$ to the $4^{\text {th }}$ century $\mathrm{AD}$.

10 ORLIĆ 1995.

11 JuRišić 2006, map 1.

12 To provide a better comparison of the individual objects, Figures

5-9 are printed in the same scale and relative orientation.

13 Minoljek 2012, 527.
Originally a porticus was attached to the NE and SW sides of the object, running parallel to the coast. Its length in the NE direction was unknown in 2014. On the SW side the portico could be followed for about $120 \mathrm{~m}$, where it seems to connect with Object B. The size of architectural remains and the quality of the uncovered archaeological finds suggest an interpretation of Object B as a villa maritima (Fig. 6). ${ }^{14}$ Since 1995, visible remains were documented and partially excavated, with the excavations mainly concentrating on the southern part of the large complex..$^{15}$

Excavations have covered a total of about 0.2 ha and revealed Roman construction phases from the $1^{\text {st }}, 2^{\text {nd }} / 3^{\text {rd }}$ and $4^{\text {th }}$ centuries AD. ${ }^{16}$ The walls were constructed in opus isodomum, opus incertum or opus mixtum. Floor surfaces are partly preserved in the form of stone plates, mosaic floors (opus tessalatum, opus sectile) or a combination of both (opus scutulatum). Also, numerous frescoes and marble remains, ${ }^{17}$ statue fragments etc. speak of an exclusive interior. In total, the complex extends over three or four terraces with a height difference of approx. $1 \mathrm{~m}$ each. In the post-Roman period the building seems to have been used for a short period of time, as the traces of fireplaces from the $6^{\text {th }}$ century reveal. ${ }^{18}$

\section{DžIN 1995.}

15 Girardi Jurkić et al. 2012 with older literature. - DžIn 2013, 70-71.

16 Girardi JURKić 2008a, 8-15.

17 Gobić Bravar 2006.

18 Girardi Jurkić 2008b. 


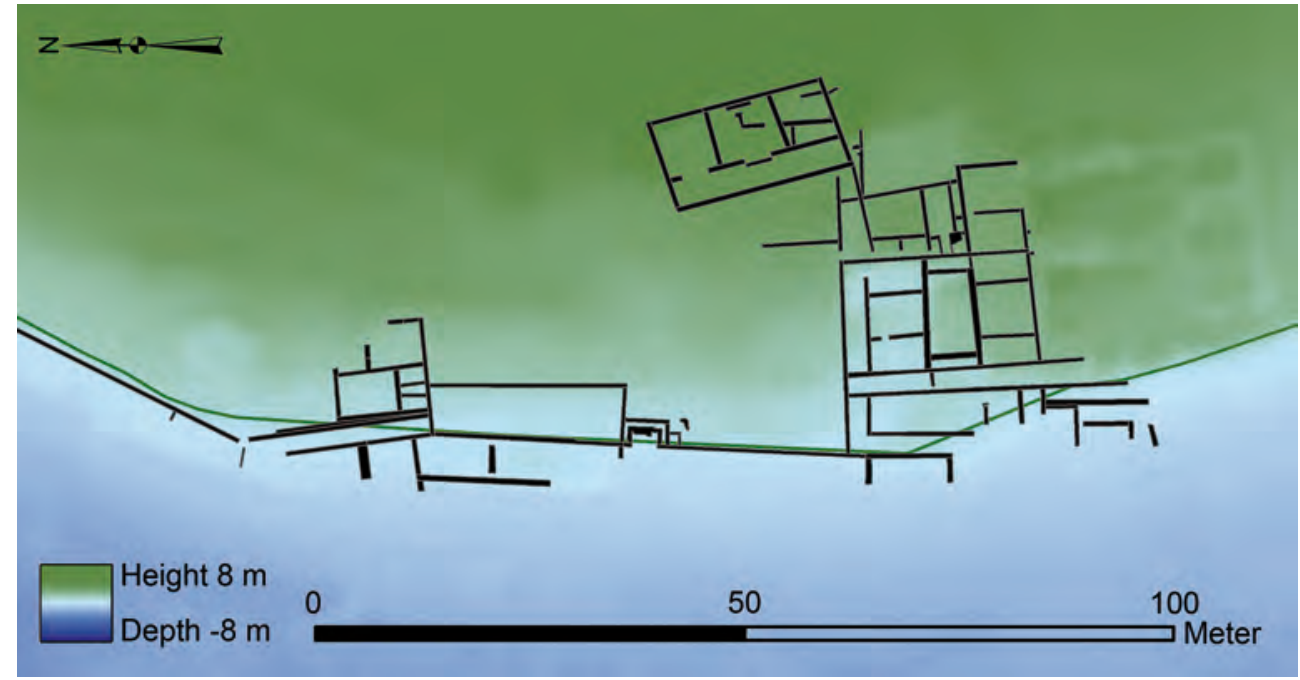

Fig. 6. Object B, state of research 2014. - The green line marks the 0 height and today's coastline (Graphic: N. Doneus).

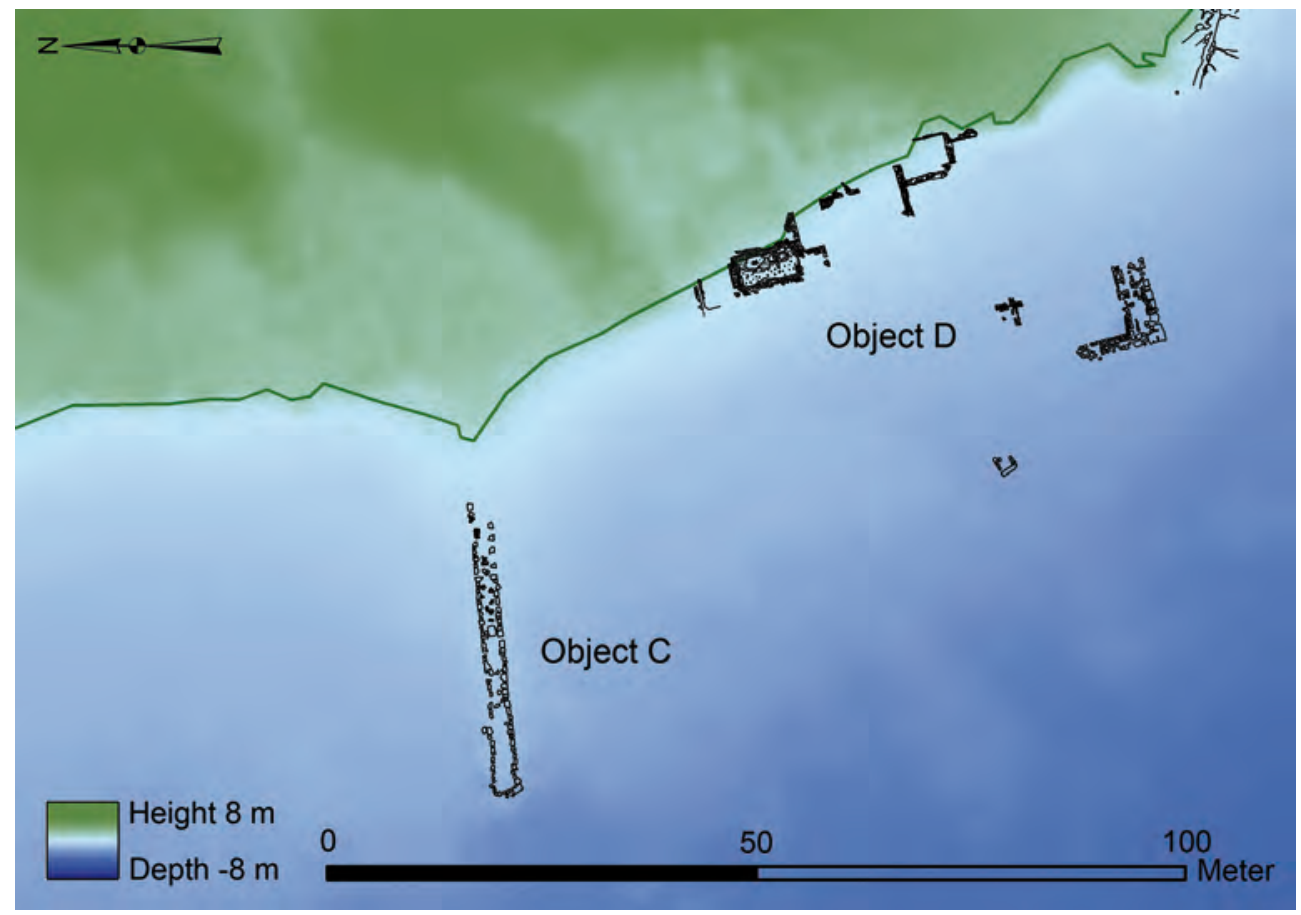

Fig. 7. Objects C and D, state of research 2014. - The green line marks the 0 height and today's coastline (Graphic: N. Doneus).

Some $100 \mathrm{~m}$ further south, the remains of a pier were located and named Object C (Fig. 7). The pier is submerged and lies in front of a disused quarry (Fig. 11). Results of underwater excavations next to the pier did not reveal any Roman or other kind of archaeological finds. ${ }^{19}$

19 Orlić 1995, 69-70. - JuRišić 2006, 303.
Southeast of the pier, on the beach and in the shallow water, there are further remains from Roman times (Object D) which include several rooms of a residential building as well as a cistern with the dimensions $6.5 \times 3.2 \mathrm{~m}$ (Fig. 7).$^{20}$

20 Minoljek 2012, 530. 


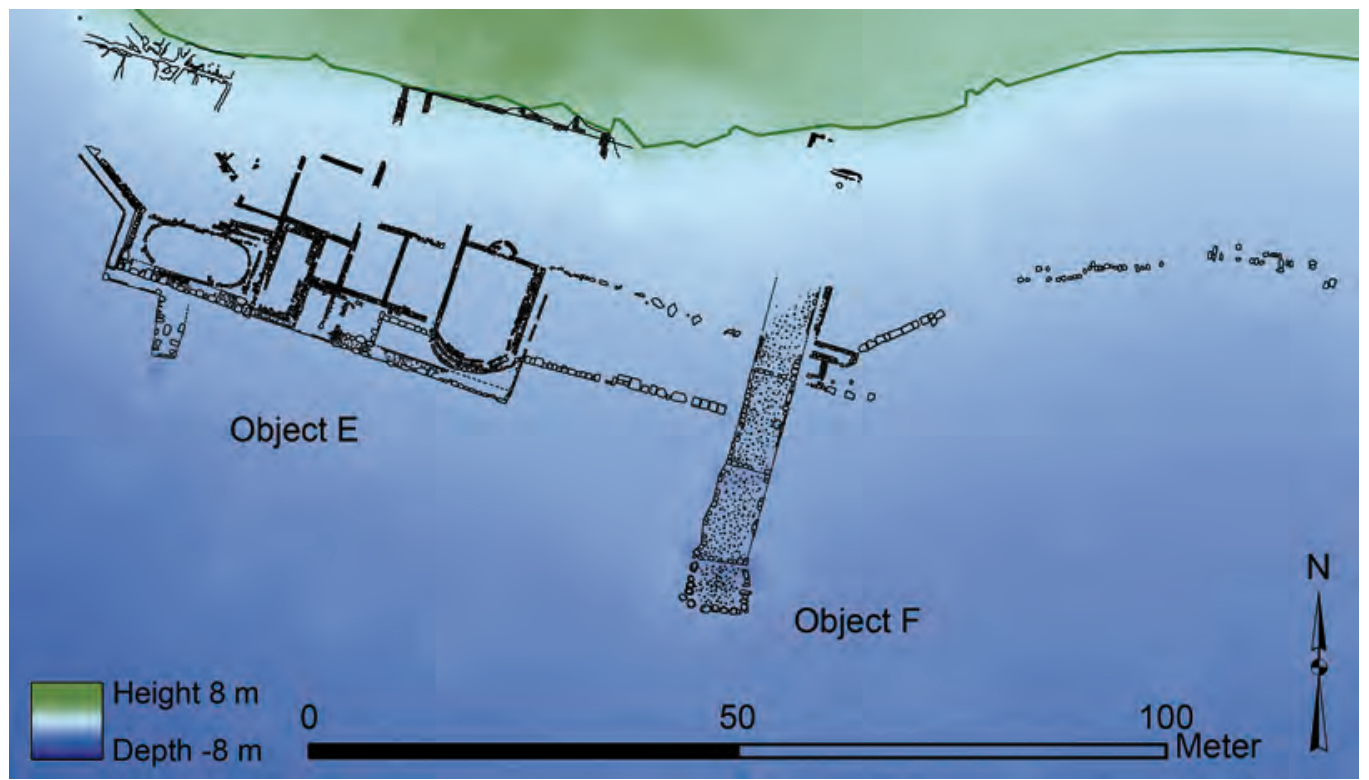

Fig. 8. Objects $\mathrm{E}$ and F, state of research 2014. - The green line marks the 0 height and today's coastline (Graphic: N. Doneus).

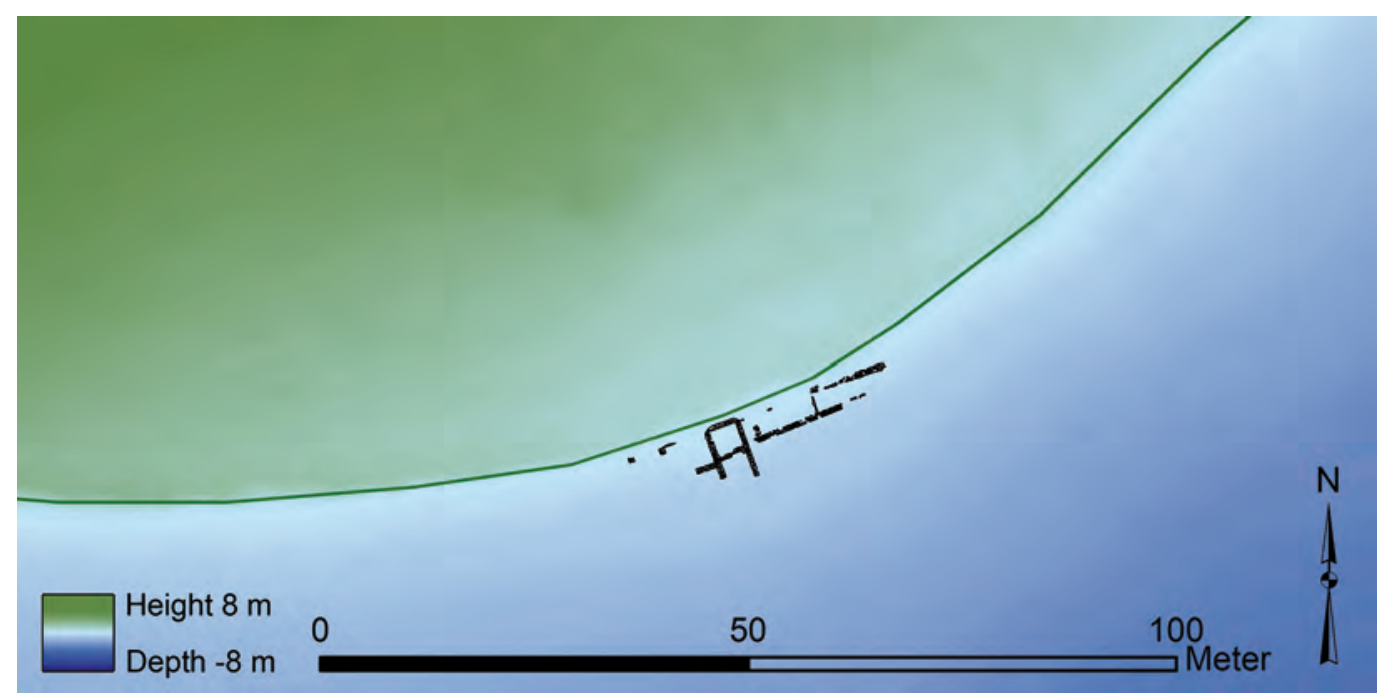

Fig. 9. Object $G$, state of research 2014. - The green line marks the 0 height and today's coastline (Graphic: N. Doneus).

Object $\mathrm{E}$ refers to parts of a larger complex $50 \mathrm{~m}$ further east (Fig. 8). The location is similar to others, as some parts are visible below water and on the beach, while others are still hidden under ground. The complex is bounded towards the sea by up to $2 \mathrm{~m}$-thick walls. It comprises several large rooms and has an adjoining pier (Object F) on the east side of the building. ${ }^{21}$

21 Miholjek 2006, 294-297.
The last Roman settlement object is located about $300 \mathrm{~m}$ further on the southern side of Vižula (Object G). As in the other cases, Roman walls can be seen in the beach area and indicate several rooms of a residential building (Fig. 9).

The Roman road (Object $\mathrm{H}$ ) is today completely submerged in the shallow water between Vižula and its hinterland (Fig. 4). ${ }^{22}$ Its course is recognizable underwater over a length of about 200 metres. Excavations have provided

22 Minoljek 2006, 298. 
information about its construction and small finds from the $1^{\text {st }}$ to the $5^{\text {th }}$ centuries AD. ${ }^{23}$ On Vižula itself the road is hidden by dense vegetation and sediments, while its remains in the urban area of Medulin have completely disappeared below modern buildings.

The nearby Burle burial ground is also part of the Roman heritage of Vižula (Fig. 4). It is situated next to the land bridge that today connects Vižula with the mainland. Systematic excavations between 1979 and 2000 revealed more than 300 cremation and skeletal burials dating from the $1^{\text {st }}$ to the $6^{\text {th }}$ century AD. ${ }^{24}$

\section{Integrating Archaeological Research in Vižula}

As can be observed from the previous chapter, our archaeological knowledge on the peninsula of Vižula is mainly based on excavations. Depending on the environment (terrestrial or underwater), independent groups of archaeologists were involved in the research, a situation, which is also reflected in the two different naming schemes or nomenclature for the archaeological features (Fig. 4). Only starting in 2014 were attempts made to integrate the archaeological research and to augment the structural information of the peninsula using large-scale archaeological prospection. Consequently, areas around Objects A, D-E and G were surveyed by high-resolution ground penetrating radar systems in 2014 and 2015.25

What is more, the EU-funded project "Archaeological Park Vižula” (2017-2019)26 offered an opportunity to further intensify the integrative approach. As well as additional underwater and terrestrial excavations, it also enabled the acquisition of remote sensing data by means of Airborne Laser Scanning (ALS) and Airborne Laser Bathymetry (ALB). All structures - terrestrial and underwater - interpreted from the ALS/ALB-based digital terrain models (DTM) were visited and verified in summer 2018 and winter 2019 by the Croatian and Austrian team members. In addition, between 2014 and 2018, Vižula was field-surveyed three times, in order to map newly eroded and thus visible architectural elements. At the same time, the documentation of underwater structures has proceeded further and delivered more information on individual buildings. The focus of this publication lies on these results, together with information from geophysical prospection and remote sensing.

23 Miholjek 2012, 527-530.

24 DŽIN 2008.

25 In the evaluation of prospection results, the naming strategy A-H was used and extended for new buildings (Object I).

26 The project was funded by the European Regional Development Fund, Competitiveness and Cohesion OP 2014-2020 and led by the Municipality of Medulin with the aim of preserving and presenting the site to the public.

\subsection{Airborne Laser Scanning/Airborne Laser Bathymetry}

Laser scanning, often referred to as LiDAR (Light Detection And Ranging), has seen increasing use in archaeology over the past two decades. Today, it has become an important component for modelling objects and terrain ${ }^{27}$ from airborne (referred to as Airborne Laser Scanning, or ALS) and terrestrial (referred to as Terrestrial Laser Scanning, or TLS) platforms. ${ }^{28}$ As active remote sensing devices, laser scanners typically send out infrared pulses towards a target surface, the backscattered echoes of which are recorded, resulting in dense point clouds of the scanned surfaces. The ability of laser scanners to record surfaces even under dense vegetation has made them viable tools for the detection of archaeological and palaeoenvironmental features in woodlands and dense macchia.

For coastal and/or submerged settlement sites the development of scanners utilizing green lasers with small footprints is of special interest. They have the capability to penetrate clear water and consequently measure the underwater topography (= Airborne Laser Bathymetry, ALB) in high detail, resulting in digital surface and terrain models with a raster width of $0.5 \mathrm{~m}$, combining the topography of underwater and terrestrial surfaces as well as the intertidal zone. ${ }^{29}$

Within the framework of the project "Archaeological Park Vižula” a flight mission was carried out in March 2018 covering - beside Vižula - the whole of Medulin Bay. ${ }^{30}$ Approx. $17 \mathrm{~km}^{2}$ were documented with an airborne RIEGL VQ-820-G laser scanner and an IGI $50 \mathrm{~mm}$ Digicam camera. The laser scan measurements resulted in a digital model of the terrestrial and underwater topography with a planimetric resolution of $50 \mathrm{~cm}$ in waters at depths of up to $10 \mathrm{~m}$. To optimize the data for archaeological purposes, the acquired georeferenced point cloud was further processed in the collaboration with the Technical University of Vienna. Details on the scanner settings and the ground point filtering process were specified in a recent publication. ${ }^{31}$

For the Roman architecture of Vižula, the inclusion of ALS/ALB in the archaeological research allowed systematic landscape-based archaeological interpretation of potential terrestrial and submerged structures. Interpretation and mapping of the relevant structures was based on standard visualization techniques such as hillshade, slope, openness,

27 Cf. Crutchley 2010. - Doneus, Briese 2011. - Opitz, Cowley 2013. - FERnANDEZ-Diaz et al. 2014.

28 Grussenmeyer et al. 2016.

29 Doneus et al. 2013. - Doneus et al. 2015. - Menna, Agrafiotis, Georgopoulos 2018.

30 An evaluation of complete ALS/ALB data, with the focus on Medulin Bay, will be presented in a separate publication. 31 Doneus, Mandlburger, Doneus 2020. 


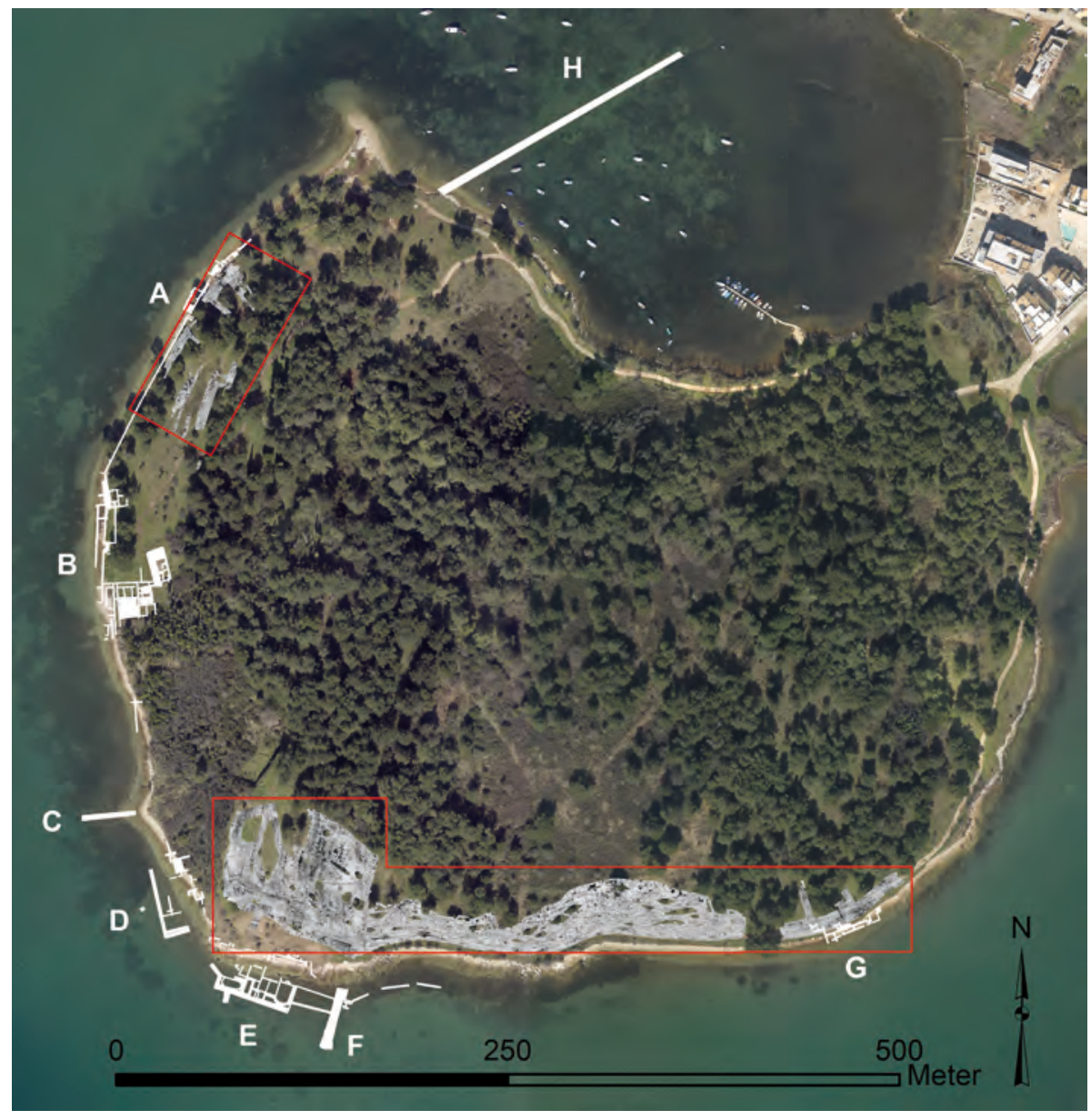

Fig. 10. Overview of the geophysical survey on Vižula (Graphic: N. Doneus, () Orthophotograph acquired during the ALS flight mission 2018). local relief model and combinations thereof. ${ }^{32}$ Furthermore, the detailed DTMs facilitated integration of a landscape context into the site-based interpretation.

\subsection{Geophysical Prospection: High-Resolution GPR}

Geophysical prospection uses diverse methods (geomagnetic, ground penetrating radar, resistivity and electromagnetic induction surveys) for the documentation of archaeological structures hidden in the shallow subsurface. The choice of the method depends on the soil, geology and structure of the site. Modern geophysical hardware and software are highly efficient and capable of excellent imaging quality. ${ }^{33}$ Magnetics and ground-penetrating radar are currently the most frequently applied methods in the context of large-scale geophysical archaeological prospection.

32 Hesse 2010. - Challis, Forlin, Kincey 2011. - Kokalj, Zakšek, Oštir 2011. - Bennett et al. 2012. - Doneus 2013. - Kokalj, ZaKŠEK, OŠtir 2013. - KoKalJ, SOMRak 2019.

33 Bevan, Smekalova 2013. - Novo 2013. - Schmidt et al. 2015. Cozzolino et al. 2018.
Magnetic measurements are most suitable for the mapping of archaeological structures which cause anomalies in the Earth's magnetic field in large, open and unobstructed areas. ${ }^{34}$ GPR provides detailed three-dimensional information about the approximate depth, shape and location of archaeological structures and is especially valuable in the study of ancient cities. ${ }^{35}$ Measurements with motorized multi-channel geophysical systems permit quick and cost-effective examination of large areas. More important, however, is the fact that in combination with other prospection and archaeological methods, large-scale geophysical prospection makes detailed research at the landscape level possible.

A first application of geophysical prospection in Vižula took place in the year 2014, followed by a second GPR campaign in 2015 (Fig. 10). Both campaigns were conducted by the Ludwig Boltzmann Institute for Archaeological Prospection and Virtual Archaeology (LBI ArchPro).

34 E.g. Doneus et al. 2018.

35 E.g. Neubauer et al. 2012. - Doneus, Doneus, EtTingerSTARČIĆ 2017. - Trinks et al. 2018. 


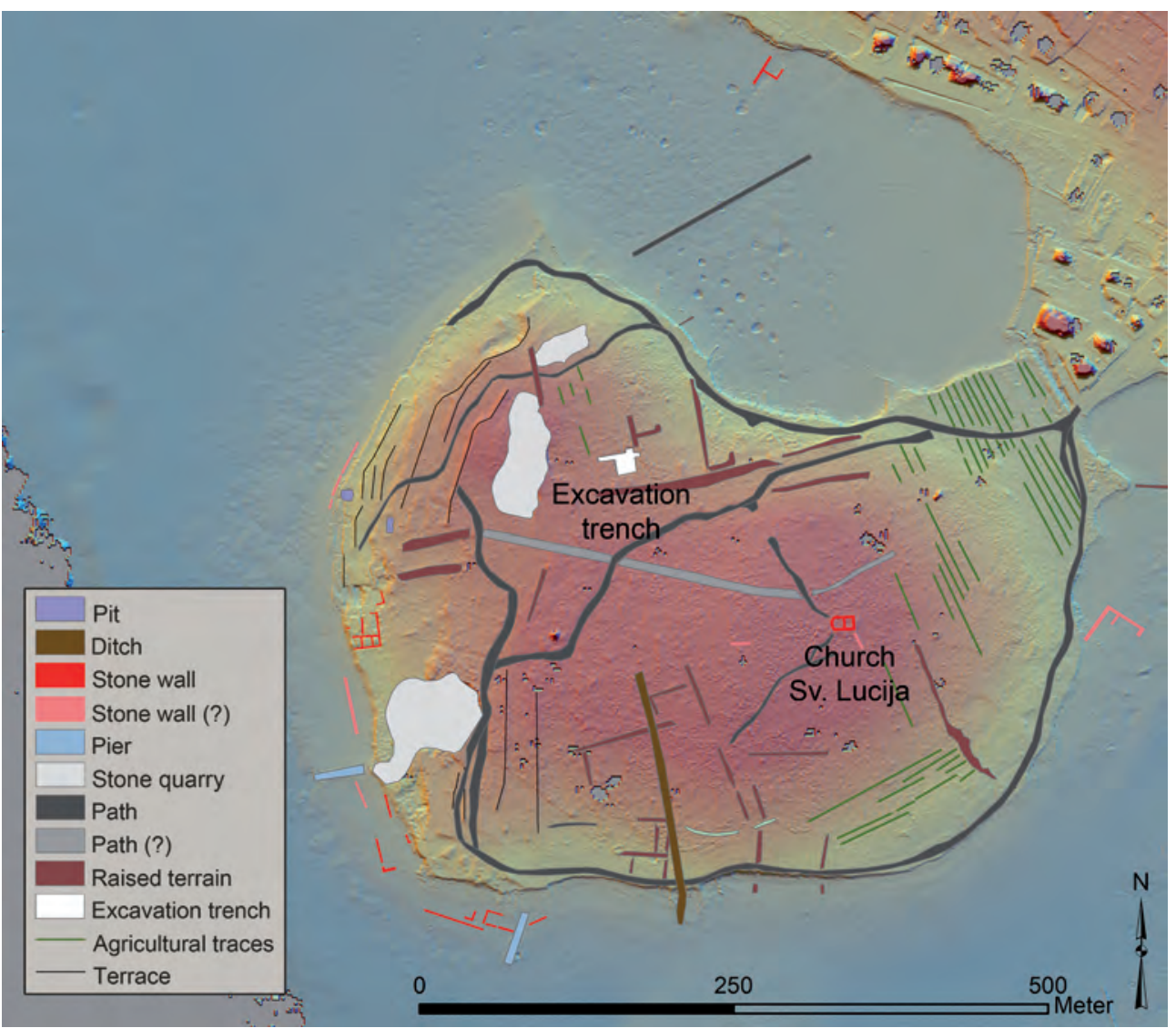

Fig. 11. Overview of ALS/ALB results (Graphic: N. Doneus). - See also the visualization of the ALS data on Figure 24.

The focus was on the areas next to Objects A, D-E and G. In the first year, the measurement was conducted using a motorized Sensors \& Software multichannel system with a six-channel $500 \mathrm{MHz}$ array (SPIDAR) and a measuring grid of $0.05 \times 0.25 \mathrm{~m}$. In the second year a different motorized system was applied, including a 16-channel $400 \mathrm{MHz}$ MALÅ Imaging Radar Array (MIRA) with $8 \mathrm{~cm}$ cross-line spacing. A total of six working days were spent on Vižula in 2014 and 2015 to measure 1.8 ha. To obtain exact geographic positioning, an RTK-GNSS system, which is also linked to real-time navigation software, was used. Here, large trees, with their wide and dense crowns, have to some extent caused problems with the positioning signal, resulting in small and patchy GPR measuring areas, as next to Object A (Fig. 13). Processing and visualization of the collected data was carried out using the software ApRadar, a collaborative in-house development of the LBI ArchPro and its partner ZAMG.

\section{Results}

The interpretative mapping of the ALS-based DTM from Vižula clearly shows - in contrast to the aerial photographs
- past landscapes containing terraces, pathways, stone quarries, walls and relics of past agricultural use (Fig. 11). However, the results are skewed: the DTM reveals only a fragmentary image of the Roman heritage of Vižula, as features of Roman origin found during field surveys were not visible in any visualization of the ALS-based DTM.

Also, submerged architecture, like the Roman road north of Vižula, was recognizable only in isolated areas (Fig. 12). This is mainly due to the fact that thick sediment packages are deposited in the shallow water covering archaeological objects. Another bias of the dataset results from the fact that ALS allows us to reveal archaeological traces that are still visible in relief. Therefore, many traces visible in the ALS data are of rather younger date. The data, on the other hand, provide valuable indications with regard to large-scale human intervention in the relief and will be discussed below.

Furthermore, geophysical results are also affected by soil properties, the predominant vegetation and the type of landscape cultivation. In addition, the duration and intensity of occupation periods influence the visual appearance of single archaeological layers in the prospection data. In Vižula, it is evident that post-Roman times played a minor 


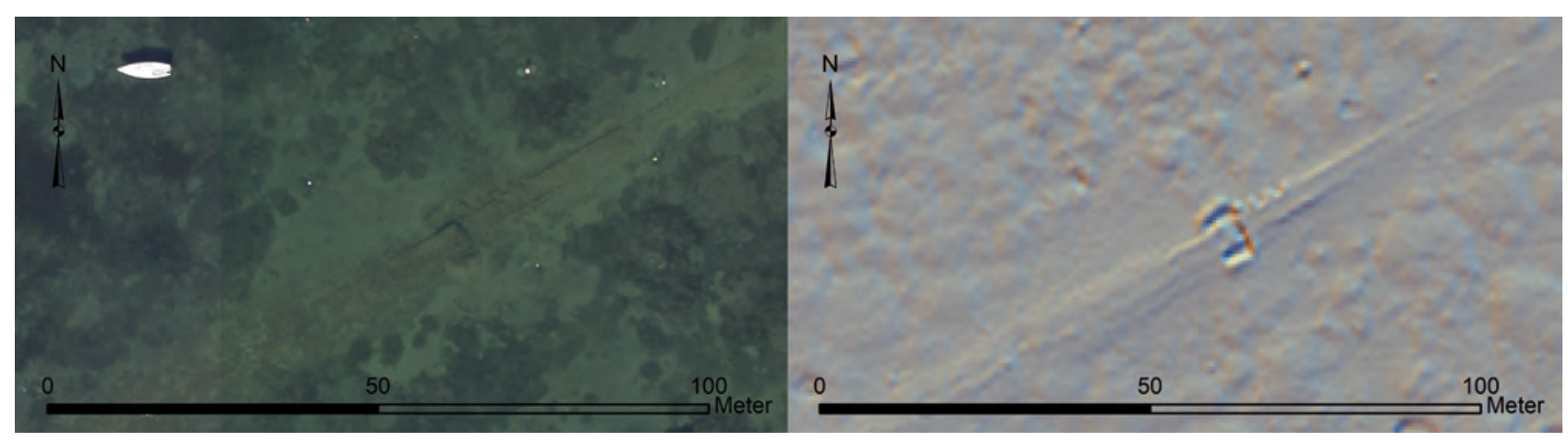

Fig. 12. Submerged Roman road and excavation trench visible in aerial photograph (left) and ALB data (right) (Graphic: N. Doneus, $\odot$ Orthophotograph acquired during the ALS flight mission 2018).

role for the visibility of Roman remains, since the site does not seem to have been inhabited since the Migration period. Here, the soil type (terra rossa ${ }^{36}$ ) and its high water content had more influence on the prospection data. ${ }^{37}$

In 2018, some of the GPR results were verified in targeted, small-scale excavations. ${ }^{38}$ The results showed that in some areas the GPR interpretation perfectly matched the excavated features (Object I, Fig. 17), while other excavated structures were hardly visible in the GPR data (Object G, Fig. 20). Individual survey areas are discussed in the following.

\subsection{Object $A$}

Structures of the building have been found underwater and in the intertidal zone. Only smaller extents were visible through geophysical measurements. Object A has a width of almost $50 \mathrm{~m}$ with outer walls recognizable by the increase of c. $20 \mathrm{~cm}$ in thickness (Fig. 13/1). In addition, this is confined on both the northern and the southern sides by a porticus with a wall width of $80-90 \mathrm{~cm}$ (Fig. 13/2). GPR data were able to confirm that further parts of the building are hidden between 10 and $90 \mathrm{~cm}$ below the surface. While the orientation clearly suggests that these walls are part of the excavated building, their low number plus the very small

\footnotetext{
36 DURn 2003.

37 In addition to GPR measurements, a preliminary geoarchaeological evaluation was taken in December 2015 by Petra Schneidhofer, LBI ArchPro for better understanding of the geophysical response to the prevailing environmental settings. Investigations included soil and sediment analyses as well as in-situ measurements of magnetic susceptibility, dielectric permittivity and electrical conductivity. 38 The documentation of the excavations 2017-2019, including the location of the test trenches, stone walls etc., is still in progress and could therefore not be integrated into the figures of this publication. Those results will be published separately.
}

number of preserved floor surfaces provided only few indications of the size and layout (Fig. 13).

Approximately $70 \mathrm{~m}$ south of Object A, GPR data indicate further settlement features. These are several round structures with a diameter of about $2 \mathrm{~m}$ with a channel in between (Figs. 13/3,14). In contrast to the walls of the villa, which appear directly below the surface in the GPR data, the structures mentioned here are only weakly visible at a depth of between 50 and $70 \mathrm{~cm}$. However, the section is too small to be considered with certainty as a production part of the villa and the features cannot be spatially assigned to a separate building.

\subsection{Object B}

Similar to most of the other known buildings on Vižula, Object B is partly submerged. While the dense vegetation surrounding the excavated area did not allow geophysical measurements, the ALS-based DTM reveals further structures of the villa maritima.

An older and obviously forgotten excavation of $\mathrm{Ob}$ ject $B$, nowadays almost completely covered by vegetation, was detected in the ALS data (Fig. 15). In an area of $25 \times$ $25 \mathrm{~m}$ several excavated walls are visible and correspond in orientation with the already known layout of Object B. Based on the topographical data it can be seen that the excavation trench was not filled in and levelled after completion of the work, the walls were left uncovered and the excavated soil deposited on the outside of the walls. The inside of the individual rooms seems to be elevated in comparison to the excavated walls, so that here, perhaps, the archaeological layers are still partly in situ. The exact date of the excavation is unknown. Presumably it is an excavation from the beginning of the $20^{\text {th }}$ century. An indication for this can be found in the photo collection of the Austro-Hungarian 


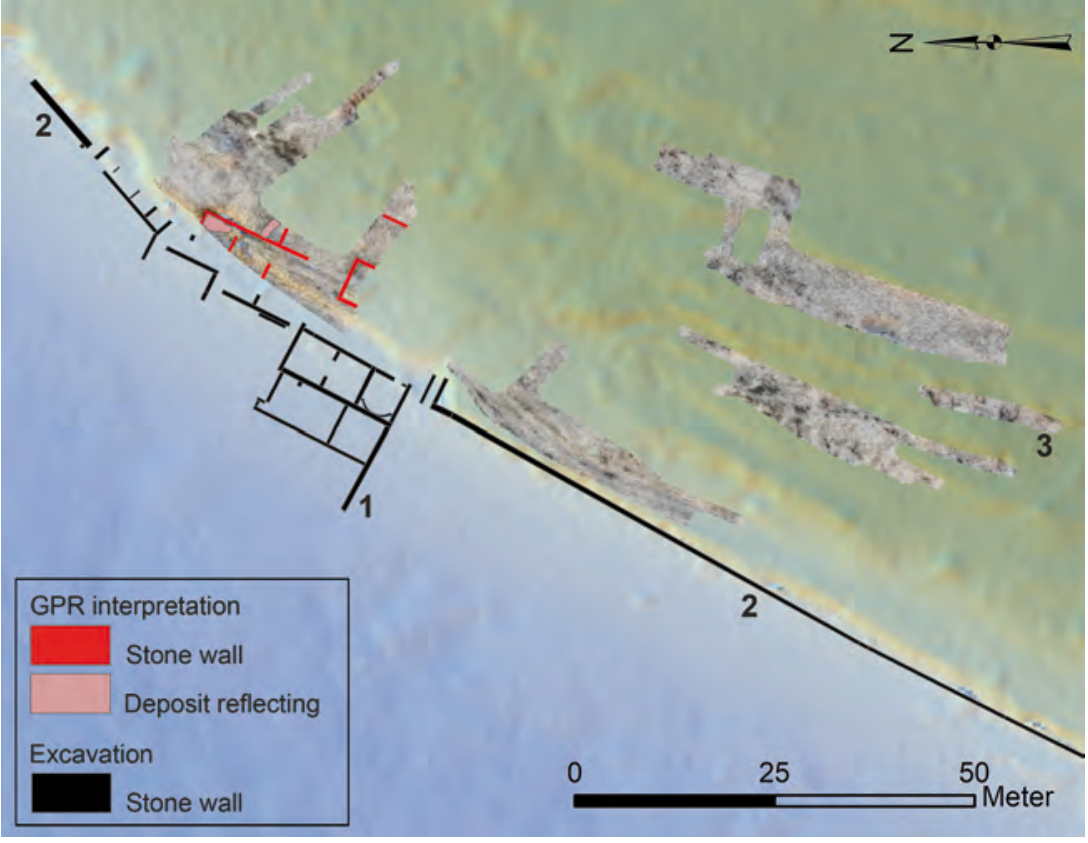

Fig. 13. Interpretation of the GPR data and underwater excavation results of Object A. 1. Outer walls. -2 . porticus. -3 . Production part of the villa (?) (Graphic: N. Doneus).

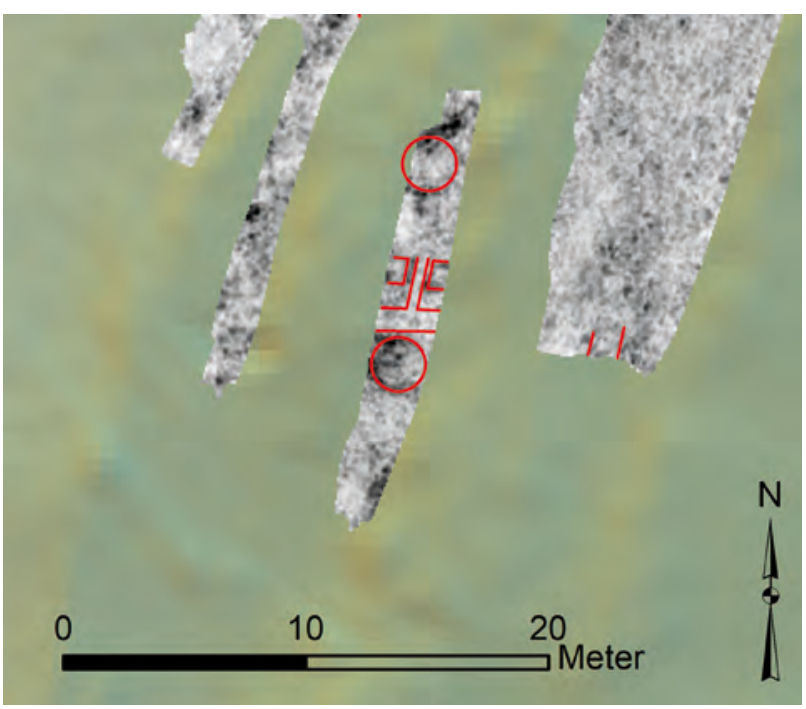

Fig. 14. Settlement features south of Object A (Graphic: N. Doneus).

artillery officer Richard Schuster. ${ }^{39}$ Mr. Schuster's note "Multicoloured mosaic fragment from the caldarium of the 'Crispus-Villa' is in my possession.” ${ }^{40}$ suggests that he not only documented Vižula photographically between 1914 and 1917, but that he also carried out his own excavations.

39 BADER 2016, 210-211.

40 BAder 2016, 211: "Mehrfarbiges Mosaikfragment aus dem Caldarium der 'Crispus-Villa'. Ist in meinem Besitz.”
Today, the mosaic is lost. ${ }^{41}$ Another indication of an old excavation is perhaps visible in the ALS-based DTM on the north side of Object $\mathrm{B}$, at the point of contact between the building and the porticus (Fig. 16/5). Here, ALS data indicate a (partial) ground-plan measuring approx. $7 \times 8 \mathrm{~m}$.

The layout of the building complex B seems to be half known. The side facing the sea extends about $120 \mathrm{~m}$ in a north-south direction and has a porticus (Fig. 16/1) in front of the residential areas. In addition to the residential wing to the south (Fig. 16/2), the building must have had at least one further wing, probably on the north side. This is not only indicated by wide stairs, which were positioned roughly in the middle of the complex and led to the sea (Fig. 16/3), but also by the current absence of a kitchen or thermal facilities. The southern residential wing had a width of $50 \mathrm{~m}$ and a length of more than $40 \mathrm{~m}$. Different orientations of individual rooms are an indication of rebuilding through time, the four rooms from the $4^{\text {th }}$ century $\mathrm{AD}$ (Fig. 16/4) in particular do not fit in their orientation with the older layout. ${ }^{42}$

The ALS data also show man-made terraces to the north of Object B (Fig. 16). They correspond to the previous excavation results, which indicate that the villa was built on three or four terraces. The difference in height between each of the terraces is about $1 \mathrm{~m}$.

41 Personal comm. Andrej Bader.

42 For details see Girardi Jurkić et al. 2012 with older literature. 


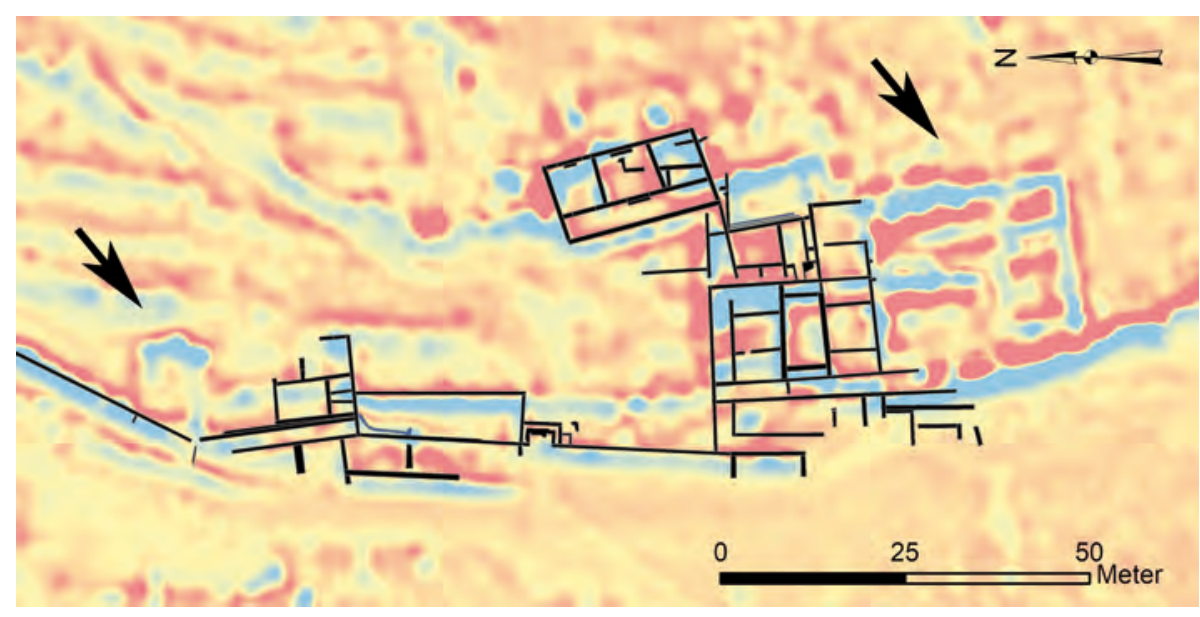

Fig. 15. Old excavation trenches north and south of Object B in the ALS data (Graphic: N. Doneus).

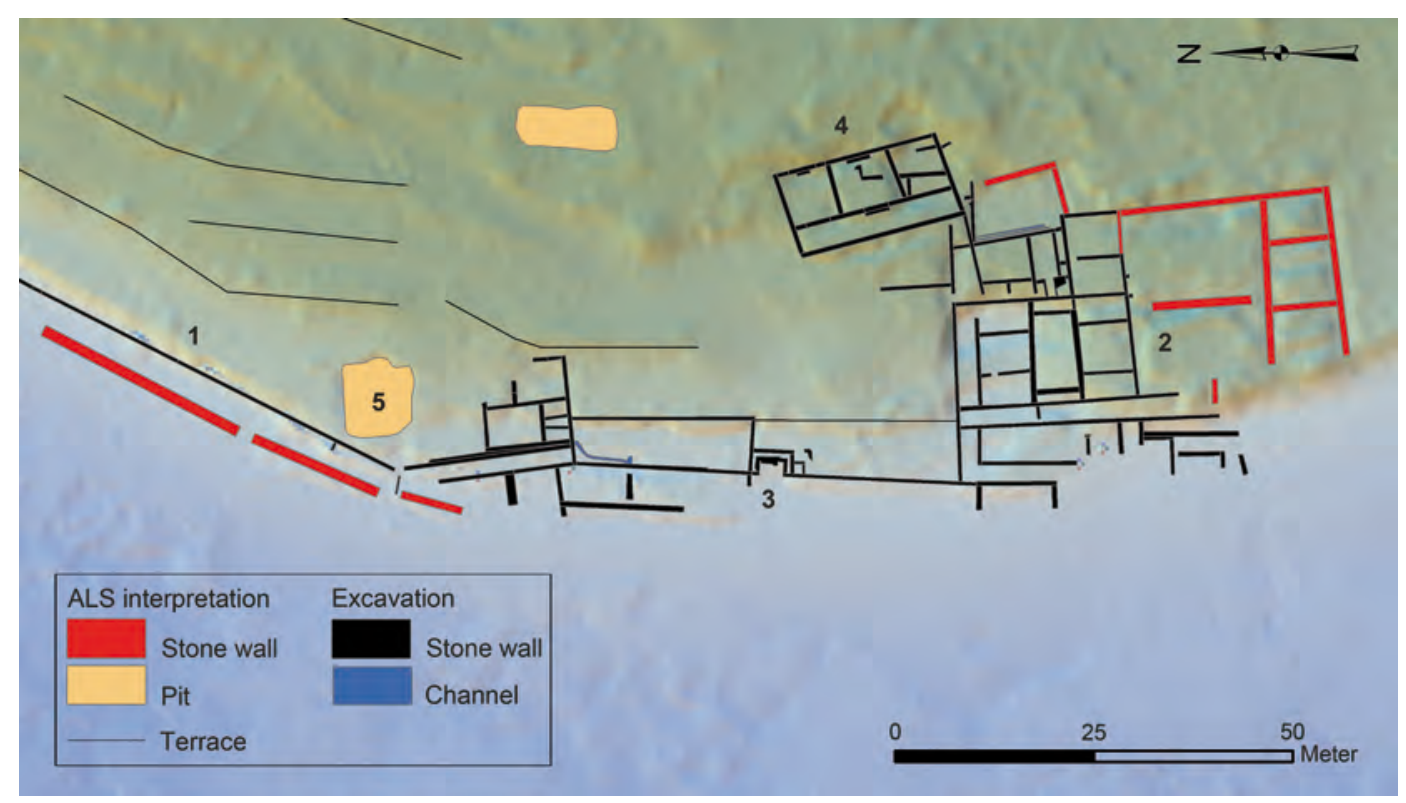

Fig. 16. Interpretation of the ALS data and excavation results of Object B. - 1. porticus. - 2. Southern part of the villa. -3 . Stairs. -4 . Building extension from the $4^{\text {th }}$ century AD. -5 . Old excavation trench (Graphic: N. Doneus).

\subsection{Object C}

The remains of a submerged pier are known as Object $\mathrm{C}$ (Figs. 4,7 ) and are located in front of a former quarry. In the quarry soft chalk limestone was exploited. ${ }^{43}$ This type of stone was used in Roman but also in more recent periods, such as during the Venetian Republic. ${ }^{44}$

43 Information taken from the unpublished report: B. CVETKo Tešović, M. JuRAčić, Kamenolom Vižula. Geološki odsjek, Prirodoslovno-matematički fakultet, Sveučilište u Zagrebu.

44 Crnković 1991.
The pier (Object C) logistically offers itself for the transport of stone material from the quarry. For this reason both were considered to belong together. During underwater excavations no Roman material was found; therefore a more recent dating of the pier was proposed. ${ }^{45}$ Other publications in the past also suggested a potential Roman dating of both the quarry and the pier. ${ }^{46}$ The interpretation as a Roman quarry also corresponded to the idea that of all the

45 ORlić 1995, 69-70. - JuRIŠIĆ 2006, 303.

46 Girardi-Jurkić 2013, 47. 
buildings on Vižula only Object B had a residential character, while the architecture extending further southwards (Objects D-F) was addressed as supporting facilities for production and transport. ${ }^{47}$ According to the new results, however, this assumption no longer seems convincing and the dating of both the pier and the quarry to a post-Roman period is probable.

Apart from the fact that no Roman material was found underwater, the pier is made of loose stones without a mortar compound, which is neither the Roman style nor the Roman standard in the region. The construction renders it unlikely that the pier could survive centuries given the strong sea currents. Furthermore, the Italian map from the early $19^{\text {th }}$ century published by Andrej Bader in $2013,{ }^{48}$ with the mole drawn in, indicates that it was functional at that time.

In addition, the quarry is located between Objects $B$ and D-F, which are only about $150 \mathrm{~m}$ apart. Contrary to the original opinion that only Object $\mathrm{B}$ was a luxurious villa, today we can assume that complex D-E also had an exclusive residential character (see section 5.1). Consequently, a quarry in operation between two luxury villae contradicts the idea of representative living, as the quarry causes a high environmental impact and is therefore difficult to combine with the idea of a luxurious retreat or otium. ${ }^{49}$ Moreover, the excavation finds from Vižula do not contain any evidence of stonemasonry activities during the Roman period. At present, there is also no evidence that the Roman pier (Object $\mathrm{F})$ was ever used for the transport of extracted stone material. If loading and possible direct processing of stone material had ever taken place next to the pier, a corresponding composition of the find material would have been revealed. ${ }^{50}$ For all of these reasons, it seems probable that the quarry and the pier can be dated to the Middle Ages or post-medieval times.

ALS results show that there are at least two more stone quarries on Vižula (Fig. 11). However, there are no written or graphic sources that would confirm dating of any of them in the Middle Ages or later.

\subsection{Objects D-F and I}

As detailed in chapter 2.2 on the research history, Object $\mathrm{D}$ and Object $\mathrm{E}$ had been regarded as two independent buildings (Fig. 4). Based on our results from underwater surveys and the mapping of the walls in the beach area between 2014 and 2018, this interpretation has to be revised: the revealed evidence strongly suggests that Objects $\mathrm{D}$ and $\mathrm{E}$ are two parts of the same building (Fig. 17). After mapping all of the

\footnotetext{
47 Miholjek 2006, 294.

48 BADER 2013, 207.

49 Marzano, MÉtraux 2018, 25-27.

50 PARICA 2012
}

surveyed walls, Objects D and E both have the same width of approx. $50 \mathrm{~m}$ facing the sea and were originally connected; the distance between them amounts to $35 \mathrm{~m}$. The width of $50 \mathrm{~m}$ is strikingly similar to the width of the south wing of Object B (Fig. 16/2). Objects D and E are oriented at about 45 degrees to each other. Another common feature is the construction of the outer walls facing the sea: they were built directly on the waterfront and were therefore strongly exposed to the impact of the waves. This fact was compensated for by the construction of extra strengthened or doubled walls with a width of 1.5 to $2 \mathrm{~m}$ (Fig. 17/1). A similar wall construction is not known from other locations on Vižula. In addition, Object $\mathrm{E}$ has an approximately $7 \mathrm{~m}$-long wall constructed perpendicular to the building (Fig. 17/2). This small construction probably did not serve as a short pier but provided support for the building in the back. The underwater excavation showed a massive construction, partly built of stone blocks with a thickness of $0.5-0.9 \mathrm{~m}$ and a width of at least $2 \mathrm{~m}^{.51}$

The width of the two parts is not only given by the layout of the walls, but also indicated by the position of the waste water pipes, which run along the outer walls of $\mathrm{D}$ and $\mathrm{E}$; the same situation was observed for Object B.

The GPR measurements allow reconstruction of the size of the residential part $\mathrm{D}$, which measures $50 \times 55 \mathrm{~m}$. Object $\mathrm{D}$ also overlaps with a newly discovered building I in the 'back' of the large complex (Fig. 17). The extent of part E could not be determined by the GPR measurements. Also, an overlap between Objects $\mathrm{E}$ and I cannot be observed in the GPR data. Altogether, it can be assumed that part $\mathrm{E}$ has the same width of $50 \mathrm{~m}$ as D but a slightly smaller length of less than $50 \mathrm{~m}$.

Both $\mathrm{D}$ and $\mathrm{E}$ have generously measured rooms of similar size to those in Object B. While mosaics from the $2^{\text {nd }} / 3^{\text {rd }}$ century were discovered during excavations in 2018 in Object $\mathrm{D},{ }^{52}$ similar remains are completely missing in the submerged part of Object $\mathrm{E}$, as it is heavily eroded, leaving only the remains of the lowest wall foundations. This is the reason why neither waterproof mortar nor hints of decoration could be documented in situ. However, fragments of bricks, marble, frescos and mosaics were found in the two underwater excavation trenches next to the building (Fig. 17/2). ${ }^{53}$

Given the bad state of preservation, the interpretation of Object $\mathrm{E}$ can only be based on the layout of the building. The ground plan suggests - with all due caution - an

51 Unpublished underwater excavation report 2012.

52 The terrestrial excavation in 2018 was located next to the walls of Object $\mathrm{D}$, which were already visible in the beach area (see Fig. 7). 53 Unpublished underwater excavation report 2012. 


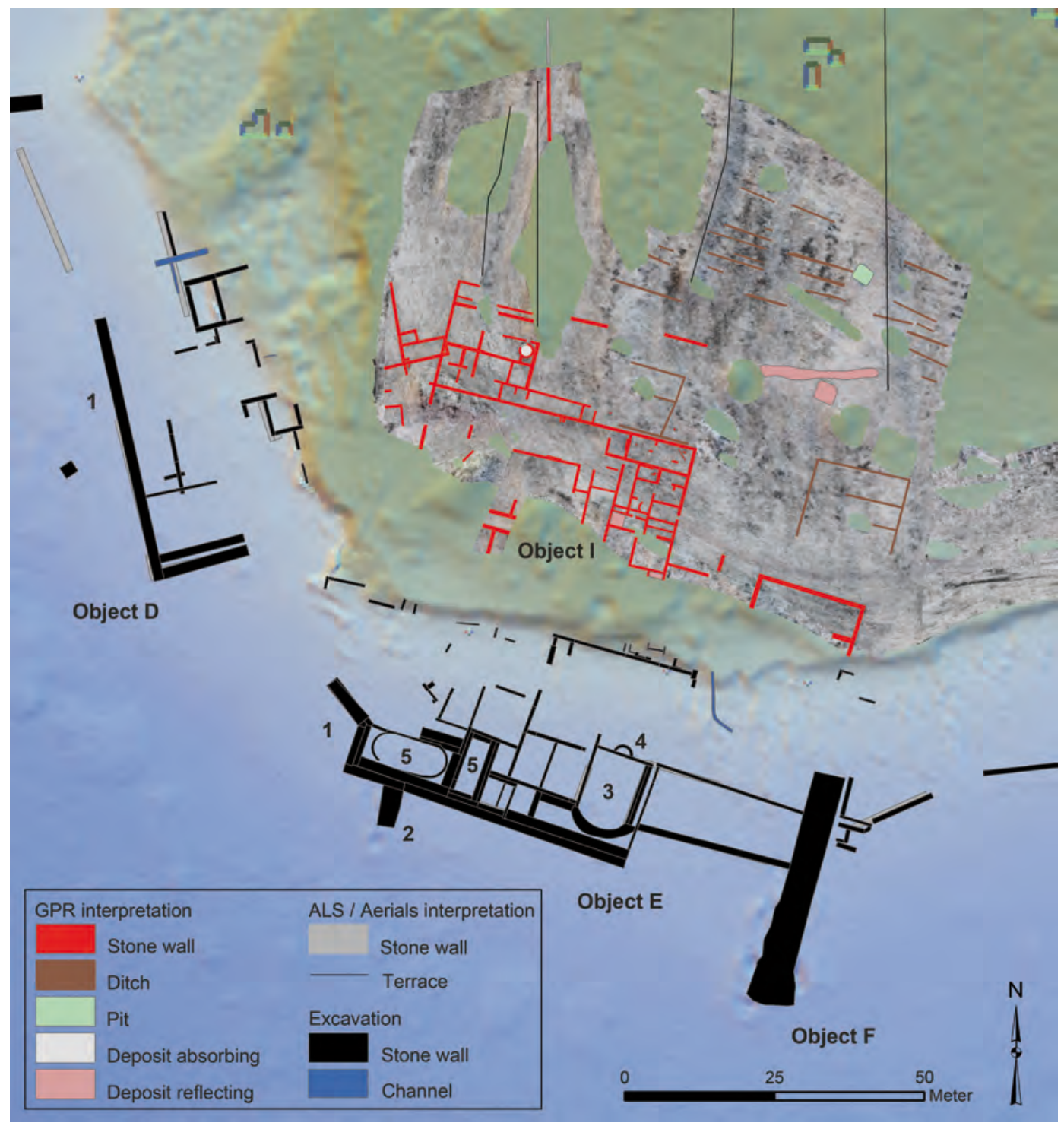

Fig. 17. Interpretation of the GPR data and underwater excavation results of Objects D-E, F and I. - 1. Outer walls. 2. Support wall. $-3-5$. Thermal part (Graphic: N. Doneus).

interpretation as the thermal part of a villa. The warm-water bath (caldarium) is possibly located in the SE, at the edge of the building (Fig. 17/3), and measures about $12.5 \mathrm{~m}$ in length and $8.5 \mathrm{~m}$ in width. The small apse measuring $2.5 \times$ $1 \mathrm{~m}$ could suggest a small piscina or a nympheum (Fig. 17/4). Two possible further basins of $15 \mathrm{~m}$ and $9 \mathrm{~m}$ in length are located on the SW side of the building (Fig. 17/5). A similarity can be found in the small bathing complex of villa Barcola near Trieste, for which a dating between the $1^{\text {st }}$ century BC and the $1^{\text {st }}$ century $\mathrm{AD}$ has been suggested. ${ }^{54}$ The layout and form of the rooms also resembles that of the villa Porto

54 Fontana 1993. - Lafon 2001, 446 dates the area (Villa del peristilo) between $75 \mathrm{BC}$ and $\mathrm{AD} 25$.
Saturo ${ }^{55}$ near Tarento, although the villa is dated to the $3^{\text {rd }}$ or early $4^{\text {th }}$ century and is therefore probably considerably younger than Object D-E. Given the significant erosion of the building, it can be assumed that the layout of Object E, as we see it today, belongs to the oldest part of the building. Based on the oldest finds from the underwater excavation, this would be the $1^{\text {st }}$ century $\mathrm{AD}$. Any later modifications have been completely destroyed by the sea.

A pier (Object $F$ ) adjoins the residential section $\mathrm{E}$ on its eastern side (Fig. 17). The area between the building and the pier consists of a $25 \mathrm{~m}$-long platform, which was artificially

55 Gualtieri 2018, Fig. 10.4. 


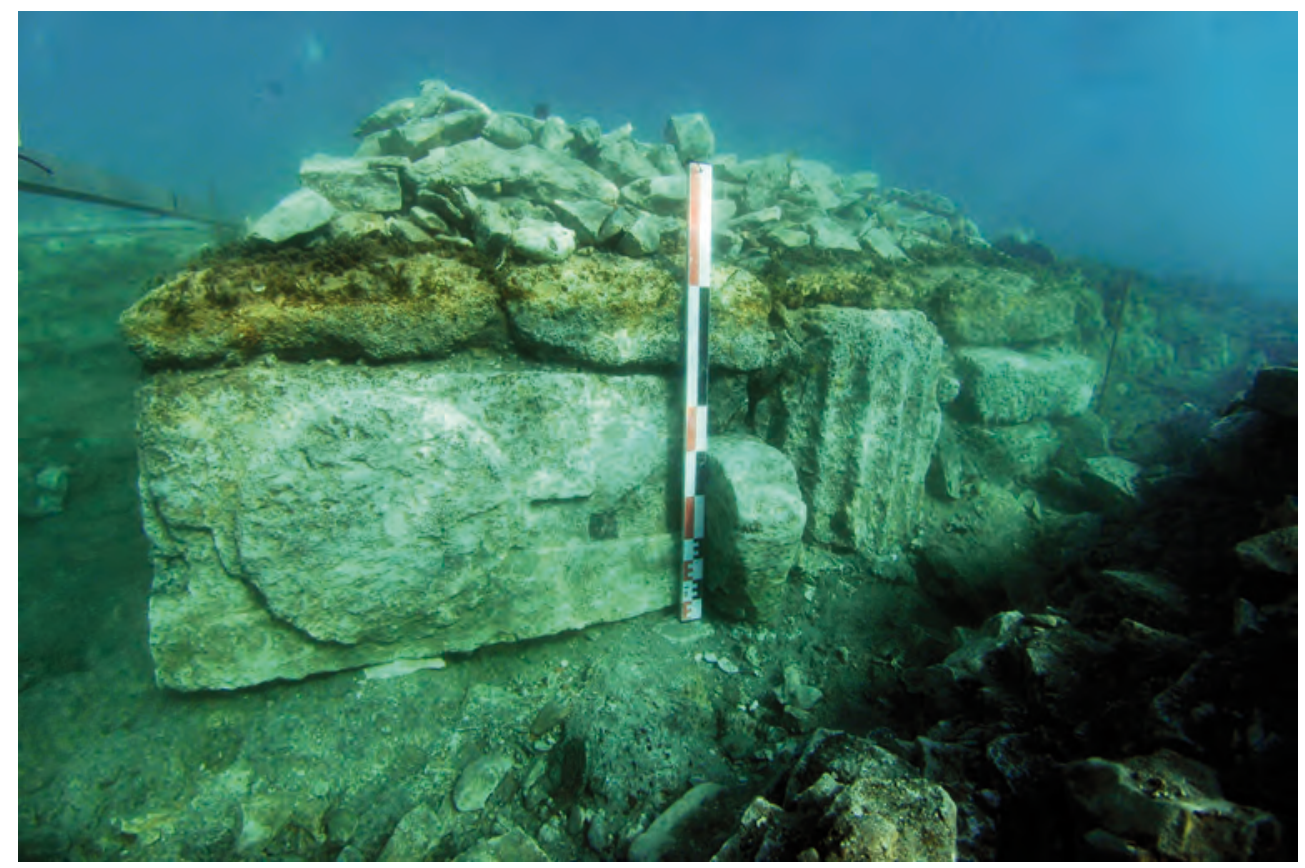

Fig. 18. The use of architectural elements for the construction of the Roman pier, Object F (@ HRZ, Croatian Conservation Institute).

filled-up and levelled. Erected stone blocks connect to the east of the pier for a length of about $50 \mathrm{~m}$ and indicate with their location the course of the coast in Roman times.

The pier is a $40 \mathrm{~m}$-long and $5 \mathrm{~m}$-wide construction, built in three parts. The outer shell is made up of larger stone blocks, the inside is filled with smaller stones, dismantled architectural elements and other 'waste' (Fig. 18). The covering of the pier is partially preserved and consists of large stone plates. The construction and the size of the object is highly comparable with other Roman piers in Istria. ${ }^{56}$ The common feature is the seemingly standardized size, with a width of 5-6 $\mathrm{m}$ on land, which is enlarged on the pier front. The length is variable and adapted to the respective topographical conditions underwater.

The GPR measurements, which focused on the hinterland of Object D-E, have resulted in the discovery of a completely unknown building (referred to as Object I). Unlike Object D-E, which was built along the shoreline, Object I is positioned towards the inland at a distance of about 20 to $30 \mathrm{~m}$ from today's beach (Fig. 17). Stone walls are visible

56 See Veštar near Rovinj for details or a summary for Roman piers in Istria in Pflederer 2014, 48 or Koncani Uhač 2018, 198-200. Both piers in Verige Bay (GNIRs 1915, Fig. 54) are of the same design as the one in Vižula, which can be seen in aerial photographs. However, they have never been a main subject of archaeological research, not even during underwater excavations in 1996-1997 in Verige Bay (BLOIER 2013). directly under the surface up to a depth of $120 \mathrm{~cm}$ in the GPR data. It is an independent building, which can be determined both from its different orientation and also from its layout (Fig. 19). Object I has an extent of $45 \mathrm{~m}$ in width and a length of at least $40 \mathrm{~m}$. The GPR data show two residential wings. The one to the north $(15 \times 17 \mathrm{~m})$ is divided into several small rooms (Fig. 19/1). In one of them, a round structure with a diameter of about 2.5 metres can be identified, which was confirmed as a kitchen oven in the excavation of 2018 (Fig. 19/2). On the western side of the residential part there is an overlap with Object D (Fig. 19/3). While both buildings show a different orientation and, most probably, did not function contemporaneously, the chronological relationship between the two of them is not entirely clear. A second residential part, located on the east side of Object I (Fig. 19/4) has a width of about $12 \mathrm{~m}$ and a length of more than $20 \mathrm{~m}$. One of the rooms might be a small storage facility (Fig. 19/5). ${ }^{57}$ The ground plan of the villa is not visible in the GPR data, which is why the location of an inner courtyard is also currently missing, but it can be expected, since a courtyard is a common feature among comparable small villae. ${ }^{58}$ Object I is a type of small villa rustica, which in Istria was

57 See comparable storage facilities in Groh, Sedlmayer 2017, Fig. 78.

58 A detailed description of villae rusticae in Istria is offered by Matijašıć 1998, 115-239. 


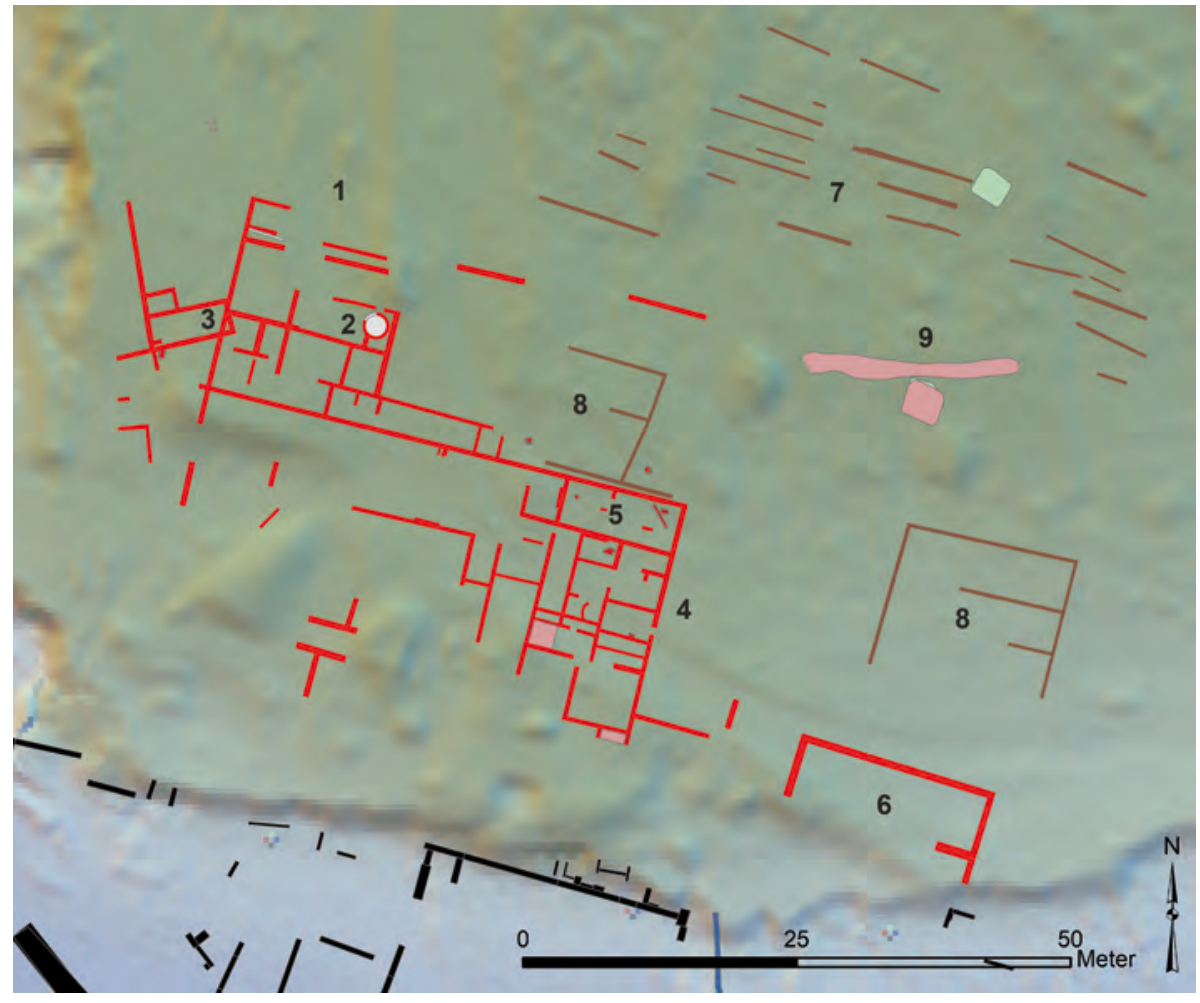

Fig. 19. Interpretation of the GPR data of Object I. - 1. Northern part of the villa. -2 . Kitchen oven. - 3. Overlap with Object D. - 4. Eastern part of the villa. - 5. Storage (?). - 6. Cistern (?). 7-8. Ditches. - 9. Path (Graphic: N. Doneus).

usually designed for combined residential and production (e.g. oil/wine) purposes. ${ }^{59}$ In terms of size, the object can be best compared with the first phase of the villa in the Bay of Verige, Brijuni Island, which, according to Anton Gnirs' documentation, is almost the same size. ${ }^{60}$ Remains of oil/ wine or any other kind of production are currently not known from the Object I.

Approximately $15 \mathrm{~m}$ east of Object I, a separate $17 \times$ $5 \mathrm{~m}$-large rectangular structure can be seen in the GPR data (Fig. 19/6). Its 60 to $80 \mathrm{~cm}$-wide walls are thicker than the walls of the residential complex $(30-50 \mathrm{~cm})$, indicating a different function. Inside the object, there is no traceable inner partition, but the data indicate a preserved floor surface. The walls are preserved to a depth of almost $1.5 \mathrm{~m}$. The simple rectangular shape of the object and the massive outer walls, in combination with the lack of interior division and a highly visible floor surface in the GPR data, allow different interpretations. One is an interpretation of the object as a cistern. Comparable water reservoirs can be found in $\mathrm{Ob}-$ jects $\mathrm{B}$ and $\mathrm{D}$ and show the same construction method with

59 Matijašıć 1998, 115-239.

60 Gnirs 1908, Fig. 9.
60-90 cm-strong walls, accompanied with waterproof mortar and opus spicatum..$^{61}$ If this interpretation is correct, it is, for the time being, the only known stand-alone cistern on Vižula and also much larger than comparable features from Objects B and D. On the other hand, the rectangular shape and the considerable size of the object are also reminiscent of a simple rectangular water basin, which could originally have been incorporated into a larger garden design of the villa Object D-E. ${ }^{62}$

Northeast of Object I, many 20 to $30 \mathrm{~cm}$-wide ditches can be found in the GPR data, which were obviously carved into the underlying rock (Fig. 19/7). Most of them run parallel in the same northeast-southwest orientation as Object I at a distance of between 1.5 and $2.5 \mathrm{~m}$ from each other. In two cases ditches form rectangles (Fig. 19/8) in the same orientation as Object I; one of them is directly adjacent to the villa. Both create individual 'plots' of about 3.5-4.5 m width and $15 \mathrm{~m}$ length. An overlap between the ditches and the walls of Object I could not be observed. All of the ditches form a system, which seems to indicate evidence of Roman

61 For Object D, see Miнoljeк 2012, 530.

62 See, for example, the typology of water basins by FARRAR 2000, Fig. page 72 . 


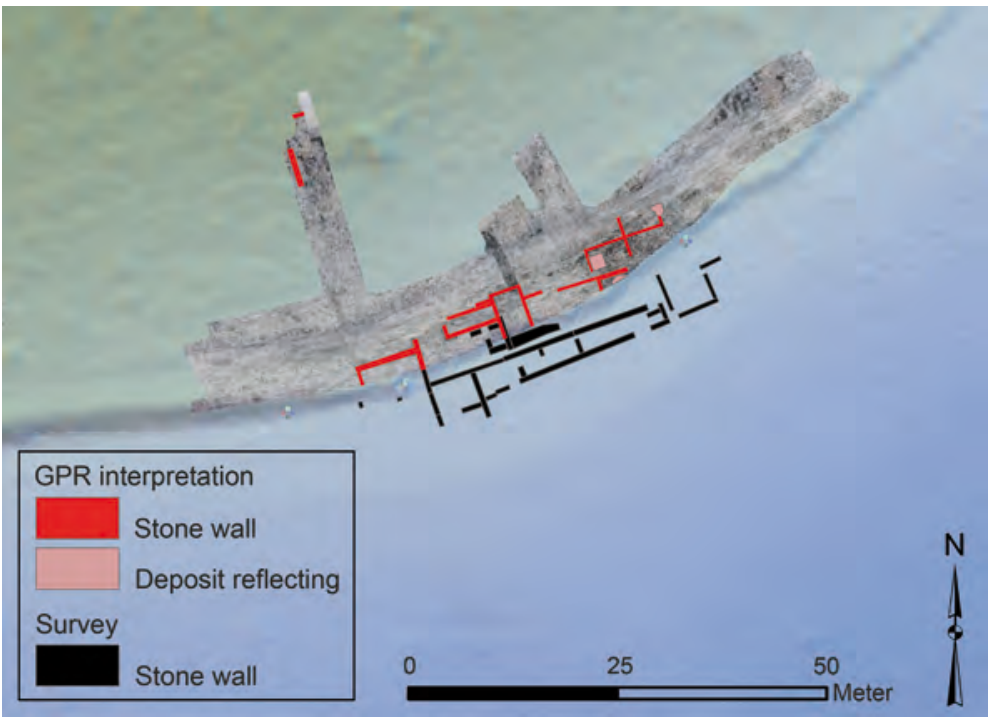

Fig. 20. Interpretation of the GPR data and survey results of Object G (Graphic: N. Doneus). agriculture, viticulture and/or garden use. Similar features were uncovered in France, England and Italy ${ }^{63}$ with a high probability of being connected to Roman wine cultivation.

Between the ditches an old path or a street is visible in the data, accompanied with a $3.3 \times 3.2$ m-large rectangular structure of unknown function (Fig. 19/9). The same path is partly visible in the ALS data, too (Fig. 23).

North of Object I, at least one wall is visible in the GPR data and aerial photographs (Fig. 17), which indicates the continuation of Roman architecture further inland. The same orientation can be observed in the four, N-S-oriented artificial terraces visible in the ALS-based DTM (Fig. 17).

\subsection{Object G}

Object $\mathrm{G}$ is located circa $300 \mathrm{~m}$ east of Objects D-E and I. The entire area in between was subjected to a geophysical survey (Fig. 10) without finding any connecting architecture. This confirms the results of the coastal survey, as no walls are visible there either. In the area of Object G, GPR measurements were able to document several previously unknown walls 30 to $80 \mathrm{~cm}$ under the ground. This proves that parts of the building are still preserved (Fig. 20). The interpretation suggests that the object is about $45 \mathrm{~m}$ wide and over $40 \mathrm{~m}$ long. A small-scale excavation in 2018, which revealed the NW corner of Object G, confirmed the GPR results and thus the approximate total size of the building. The different orientation of the walls in the south of the building is to be understood as an indication of the multiphase nature of the building.

63 Boissinot 1995 presents traces of Hellenistic vineyards in this publication. - Brown et al. 2001. - VOLPe 2009.
Surface finds offer no mosaic and fresco remains or other references to a sophisticated decoration of the object. If we also consider the size of the building, the conclusion can be drawn that Object $\mathrm{G}$ is a second villa rustica on Vižula. It is of the same size and probably also function as Object I.

\subsection{Further Results}

Various visualizations of the ALS-based DTM of Vižula show a wide range of traces of human interventions in the past. Amongst others, a former excavation from the $1960 \mathrm{~s},{ }^{64}$ which uncovered a Neolithic settlement, could be re-located by the relief-traces of the trenches (Fig. 11).

On the topographically highest point in the centre of Vižula, the DTM shows the ground plan of a building (Fig. 11) measuring $19 \times 11 \mathrm{~m}$ and seemingly divided into two parts. At least two paths lead to the building, both of them almost invisible in the terrain today. It is likely that the building represents the remains of the church Sv. Lucija, which was mentioned in written texts from $1570^{65}$ and possibly marked on a map from $1563 .{ }^{66}$

Other anthropogenic structures can also be identified in the surface relief of Vižula. Three quarries have been located on the west side of the peninsula (Fig. 11). On the east side numerous parallel lines at a distance of 4 to $6 \mathrm{~m}$ from each other were identified (Fig. 21). These most likely represent traces of past cultivation of Vižula.

Written and image sources from the Middle Ages and early modern times referring to Medulin are available, but

\footnotetext{
64 BAČIĆ 1969.

65 Personal comm. Andrej Bader.

66 BERTošA 2013, 108.
} 


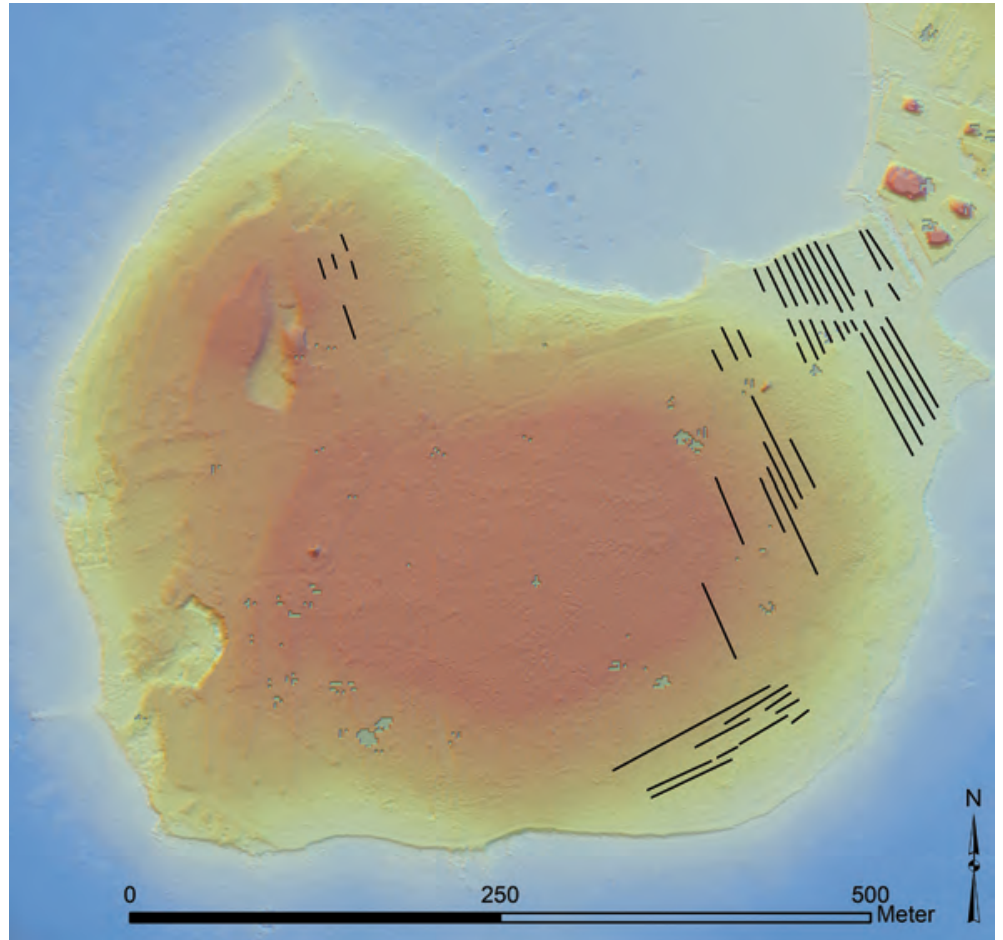

Fig. 21. Agricultural traces in the form of parallel lines on Vižula (Graphic: N. Doneus).
Vižula itself is rarely mentioned. ${ }^{67}$ The youngest settlement remains on the peninsula - except the church Sv. Lucija from the Middle Ages - date to the $6^{\text {th }}$ century AD. Whether other settlements recurred in the following centuries is not recorded and the cadastral plan from 1820 also shows an unoccupied and seemingly unused peninsula. ${ }^{68}$ Vižula must have had a certain agricultural value over the centuries, despite the lack of actual settlement activities on the peninsula. ${ }^{69}$ However, this could not be proven during a survey and apart from a single planted olive tree, no hints of more recent agricultural use were found.

Nevertheless, the traces found in the ALS-based DTM may be agricultural in origin. Neither their age nor their original agricultural significance is currently clear. It cannot be denied that at first sight these features have similarities with Roman vineyards in other provinces even though the measured distances between individual lines may vary. ${ }^{70}$ Roman viticulture appears in the form of long, parallel trenches, similar to the GPR results next to Object I (Fig. 19/7). From the ALS data, however, it is not clear whether the lines, which appear as a combination of slight

67 Summary in BERToša 2013.

68 Percan 2013, 163.

69 The use of the peninsula for sheep farming is known at least for the $19^{\text {th }}$ century. Personal comm. Andrej Bader.

70 Boissinot 1995. - Brown et al. 2001. - Volpe 2009. elevation and depression, actually display ditches below or banks above the general relief. At the same time, ALS data from the nearby area show similar patterns - parallel lines at a distance of 5-6 m - in areas of modern olive tree plantations (Fig. 22). As there are no comparable results in the region for either wine or olive tree cultivation in the Middle Ages and post-medieval periods, ${ }^{71}$ it may also be that these relics originate from more recent history.

\section{Discussion}

The long settlement history $\left(1^{\text {st }}-5^{\text {th }} / 6^{\text {th }}\right.$ century) certainly implies changes in the layout or purposes of individual buildings. However, the analysis of individual construction or chronological phases would go beyond the scope of this paper. Furthermore, due to the high erosion of the submerged features, underwater excavations offer hardly any possibilities for dating individual phases on the basis of finds in stratigraphic layers. Results from terrestrial excavations from the years 2017-2019 are currently being evaluated and will be published separately. Without taking these into consideration, it would also not be possible to determine the chronological development of single buildings at

71 See a similar lack of sources for France in Boissinot, Puig 1995. - Traces of Roman agriculture are known from the Premantura peninsula, on the opposite side of Medulin Bay, but they have been preserved in the form of individual plant pits: MatiJAšić 2012. 


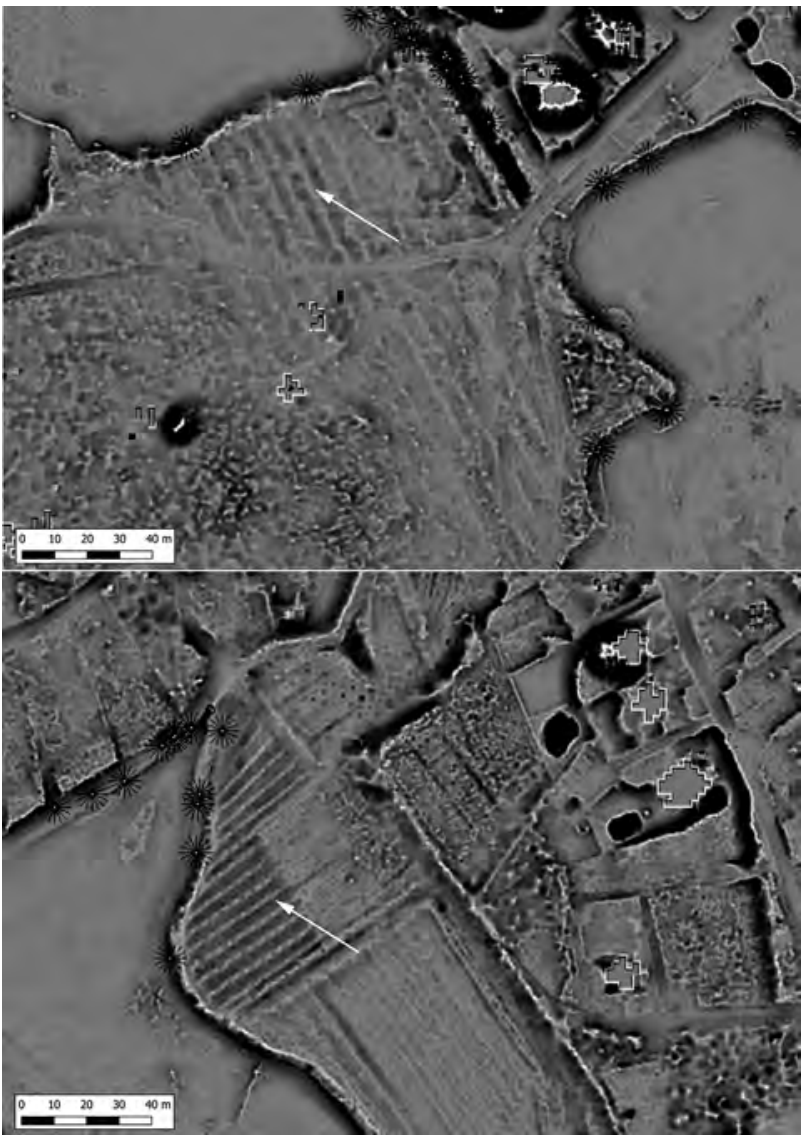

Fig. 22. A comparison between the agricultural traces found on Vižula (top) and a modern olive tree plantation in Medulin (bottom) (Graphic: M. Doneus).

the moment. Regardless of these limitations, the new results presented here provide enough evidence for discussion.

\subsection{Roman Architecture and Landscape Context}

Due to the fact that the peninsula of Vižula forms a consistent area with Roman architecture spread all along the coastline, its interpretation has always been more difficult than other smaller sites. For a long time, the Roman architecture of Vižula was considered to belong together and to be one of the largest of its kind in Istria. ${ }^{72}$ Object B was doubtless identified very early as a villa maritima and this probably had a biasing impact on the interpretation of other architectural elements scattered all over the peninsula. The idea that “...some higher developed object in its centre (serves) as the central link...”73 originates from the publication by Gnirs dealing with Roman villae in Istria in 1910. As a

72 Begović DvoržAK, DvoržAK Schrunk 2004, 68.

73 GNiRs 1910, 123: “...und irgendein höher entwickeltes Objekt in ihrer Mitte (diente) als zentrales Glied.” consequence, a central object was also assumed for Vižula and all the other Roman remains automatically became 'background'. This seemed to be further confirmed by the fact that none of the other buildings could compare in their size, quality or luxurious interior with Object B. Therefore, they were assigned secondary importance and were interpreted as the villa maritima's supporting buildings for production, storage and transport.

An integrated view of Vižula's architecture, overcoming the border between underwater and terrestrial research and including archaeological prospection, provides an opportunity to evaluate this architecture from a new and different perspective. As could be shown throughout this paper, it became apparent that some of the objects needed to be reinterpreted and that the building remains of Objects A to $G$ cannot be assigned to a single Roman complex. The Roman architecture of Vižula rather belongs to several individual sites with different functions. For some of these objects we would therefore like to offer a new interpretation:

- Objects A and B belong to one large complex, where Object $\mathrm{B}$ is the luxurious residence (villa maritima) and Object $\mathrm{A}$ an accompanying unit.

- Object $\mathrm{C}$ is a post-Roman (maybe modern) pier.

- Objects D and E belong together and form a second luxurious residence on Vižula (villa maritima); the Roman pier (Object F) directly adjoins the residential premises.

- Object I is an independent building (villa rustica).

- Object G is also an independent smaller object (villa rustica).

- Object H refers to the Roman road.

The building complexes, both the villae maritimae and the villae rusticae, are oriented parallel to the coastline. Therefore, each complex has a different absolute orientation (Fig. 23) and the villae maritimae even have different orientations within their buildings. Despite a similar orientation towards the coast, a difference between the two villae types can be seen in their location: while the two villae maritimae are positioned directly adjacent to the sea, the two villae rusticae lie slightly more inland having no direct contact to the shore.

The new interpretation of Object D-E as a second villa maritima, and consequently the merging of two parts of the building into a single object, leads to the recognition of the regularities in the location of the objects on Vižula: it is remarkable that along the coast equal distances of $120 \mathrm{~m}$ between the individual buildings are respected (excluding the villae rusticae). Measured from the outer walls of single 


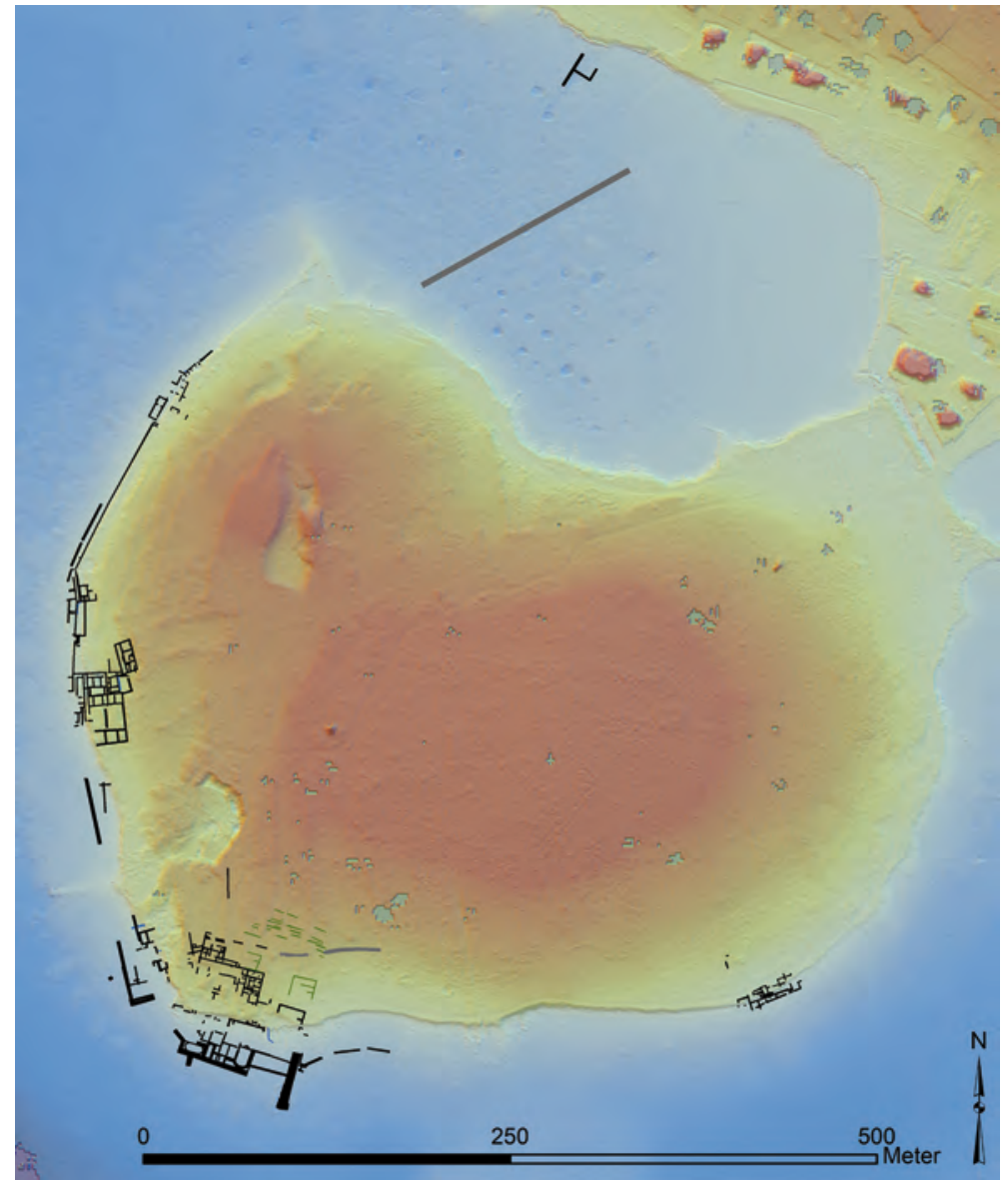

Fig. 23. Overall view of the Roman heritage on Vižula based on prospection, excavation and survey results (Graphic: N. Doneus). buildings, a distance of $110 \mathrm{~m}$ lies between the road (Object $\mathrm{H}$ ) and Object $\mathrm{A}$, followed by $120 \mathrm{~m}$ spaces between Objects A and B as well as between Objects B and D-E. This speaks for a deliberate planning but also for an exact land division in this coastal section. The two smaller Objects I and $G$ do not seem to have been included in this concept. ${ }^{74}$

There also seems to be a certain uniformity in the sizes of individual buildings. With the overall length of Object B, the distance of $120 \mathrm{~m}$ is repeated. Object D-E, measured in a straight line between the outer SE and NW corner of the building, is about $130 \mathrm{~m}$ wide. The two villae rusticae are quite similar in size, $45 \mathrm{~m}$ wide and just over $40 \mathrm{~m}$ long. Also the two villae maritimae are very similar in their dimensions, as the width of each residential wing amounts to $50 \mathrm{~m}$ in each of them. Compared to each other, the size of a villa rustica almost exactly corresponds to the size of a single residential wing of a villa maritima; or in other words, the

74 The question of how exactly the land was allocated to villae of different sizes and functions and whether a pattern can be identified can only be addressed on a larger scale. For this topic, see, for example, SCHUCANy 2011. total size of a villa rustica is at most half of the size of a main residentual building in a villa maritima.

The chronological question of the architecture of Vižula is currently not resolved. So far, only a few individual construction periods of Object B are known and they include four centuries of Roman settlement activities. The observed distance of 110-120 m between Objects A, B and D-E indicates planned building acitivities and a simultaneity of at least the villae maritimae. Objects A and B are connected with a porticus running along the coast. Due to this common architectural aspect, the two buildings are connected with each other - at least during one construction phase - and are thus in contemporary use. Although Object A shows remains of high quality decoration (e.g. mosaics from the $1^{\text {st }} / 2^{\text {nd }}$ century), the size of its individual rooms is relatively small compared to Object $\mathrm{B}$. That suggests that $\mathrm{A}$ is an accompanying object of the main residential building $(\mathrm{Ob}-$ ject B).

The spatial and temporal relationship between the two villae maritimae also requires further research. If the dating of the quarry to the post-Roman period is correct, the quarry complex could also have destroyed a possible 
architectural connection between Objects B and D-E. The latest ALS data (Fig. 11) and underwater survey results have shown that further Roman walls, hidden in the shallow water sediments, cannot be completely excluded.

In the older literature Vižula is sometimes referred to as a luxurious imperial villa of the $4^{\text {th }}$ century i.e. the 'villa of Crispus'. ${ }^{75}$ This hypothesis is based on the note of Ammianus Marcellinus, who reported the death of Crispus in Pula. ${ }^{76}$ In this context, the villa on Vižula is supposed to be the location where the Emperor Constantine the Great imprisoned his son Crispus before he was executed in the year 326. However, this theory could not be confirmed, as so far just a single small residential wing in Object $\mathrm{B}$ can be dated to the $4^{\text {th }}$ century. No other currently known architecture from Vižula matches the layout of a luxurious villa from the $4^{\text {th }}$ century.

While a construction at the beginning of the $1^{\text {st }}$ century $A D$ is assumed for Object $B$, we can only speculate about the date of construction for Object D-E. A certain contemporaneity with Object $\mathrm{B}$ is probable and there is little reason not to consider the origin of Object $\mathrm{D}-\mathrm{E}$ during the same time. Support for this date is based on finds dating to the $1^{\text {st }}$ century from underwater excavations next to Object $\mathrm{D}-\mathrm{E}$. The same is true for the end of use, as there are again just rough indicators for the length of use of Object D-E until the $4^{\text {th }}$ or $5^{\text {th }}$ century AD.

The absence of a vivarium, at both Object B and D-E, is maybe the result of the strong sedimentation rate underwater. A fishpond usually accompanies villae maritimae of the $1^{\text {st }}$ century $\mathrm{AD}$ and may therefore be discovered during further research. ${ }^{77}$

Although the architecture of Vižula can be compared in its size to that of Verige Bay, Brijuni, ${ }^{78}$ which is the largest and most impressive of its kind in Istria, it does not reach its variety and level of sophistication. This may be due to chronological reasons or to the different status of the owner.

The dating of the villae rusticae is likewise difficult. It is quite possible that villa rustica I was overlain by the later luxury building $\mathrm{D}-\mathrm{E}$, as such examples are known from Istria. ${ }^{79}$ For the dating of the second villa rustica $\mathrm{G}$, perhaps

75 A summary of the relevant literature can be found in GIRARDi-JURKIĆ 2013, 51.

76 Pohlsander 1984, 99.

77 E.g. Verige Bay, Brijuni in JuRIšrć 1997.

78 Even though the villa in Verige Bay is covered in many different publications, the original one by GNIRs 1915 still deserves to be mentioned, as it provides a large quantity of detailed information not mentioned in later publications.

79 GNIRs 1915, 116. the evaluation of the latest excavation results will provide new evidence.

A better dating of the individual objects would not only help to explain their relationship to each other but also contribute to a better understanding of the agricultural use of Vižula in Roman times. Traces of agriculture can be made visible through various ALS visualizations which allow us to enhance features in low relief and therefore to identify archaeological contexts otherwise not visible. Of special interest is the so-called local relief model, ${ }^{80}$ which highlights even extremely shallow local terrain variations. The calculation of relative terrain variations is thereby calculated for the local neighbourhood (kernel) of each raster element of the DTM. The size of the kernel is determined by the user. To be able to identify archaeological structures, the kernel size is usually set to values between 10 and 25 metres. Large kernel sizes emphasize larger-scaled 'background' structures. Using a large kernel size of $50 \mathrm{~m}$ will therefore highlight general trends in the topography.

In Vižula, the local relief model calculated with a kernel size of $50 \mathrm{~m}$ reveals two different areas (Fig. 24). The area parallel to the western coast up to a distance between 150 and $200 \mathrm{~m}$ inside the peninsula is terraced. This area includes both villae maritimae as well as Objects A and H (Roman road). The centre and eastern part of Vižula display a different general topography: it is a topographically smoother landscape without terracing. The DTM shows parallel linear structures in the eastern end of the peninsula and shallow linear banks, which have the same orientation. In the area of the villa rustica (Object $\mathrm{G}$ ) plant rows are oriented parallel with the villa. Towards the north, the plant rows seem to be bounded by a straight, bank-like structure.

Based on these observations, the central and eastern area might be interpreted as an agri- or horticultural area. If it is of Roman origin, then it might indicate a split use of the peninsula: a representative western part dominated by villae maritimae and accompanying buildings with outlooks towards Medulin Bay and an agri- or horticulturally used central and eastern part with two villae rusticae. This hypothetical reconstruction, however, needs confirmation from further research.

\subsection{Coastal Changes}

During the last millennia, a gentle, slowly progressing change of the Istrian coastline took place under the influence of natural factors like sedimentation, erosion and the continuous rise of the sea level. Anthropogenic factors have

80 Hesse 2010. 


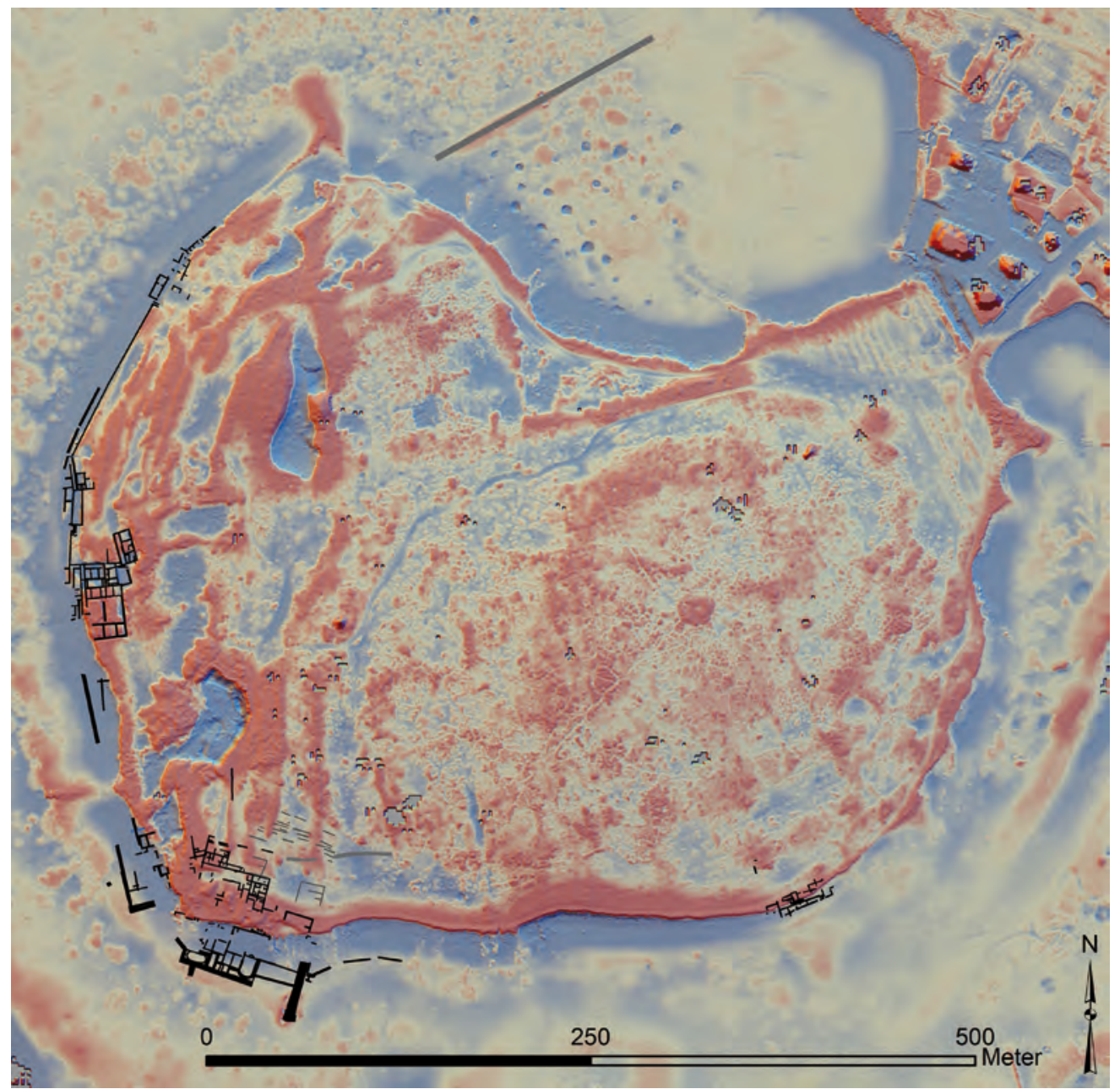

Fig. 24. Calculating a local relief model with a kernel size of $50 \mathrm{~m}$ reveals a division of Vižula into two areas, which might result from a different landscape use (Graphic: M. Doneus).

also exerted their influence on the regional-scale landscape change, most importantly through agricultural use and the exploitation of raw materials. In recent decades, building activities for the needs of an enormous tourism industry have caused the most significant changes.

Considerations about the course of the coast in ancient times have been integrated into Croatian archaeological research for a long time. ${ }^{81}$ Geological research indicates that the Adriatic coast from the Gulf of Trieste to southern Istria has tectonically subsided by about $1.5 \mathrm{~m}$ since Roman times. ${ }^{82}$ In general, Sanja Faivre et al. $2010^{83}$ estimate a sea

81 Kozličić 1986, Tab. XXI. - A summary of the current literature can be found in VACCHI et al. 2016.

82 Antonioli et al. 2007.

83 Faivre et al. 2010. level rise of 1-1.5 m for Istria. Erica Florido et al. 2011, ${ }^{84}$ however, suggest a rise in sea level in Istria since Roman times of about $1.6 \mathrm{~m} \pm 20 \mathrm{~cm}$. These general considerations are valid for whole regions, but represent only one component responsible for coastal changes on local scales. For Vižula, it would be particularly important to investigate erosion and sedimentation processes to model the water depth in Roman times, as it is precisely these forces that have most changed the underwater topography. The shallow water surrounding the peninsula shows thick layers of deposited sediments, which indicates strong inland erosion. Stormy SE winds play an important role in this process by eroding land sediments and transporting them into the sea.

Over time, these processes uncovered the architectural elements in the intertidal zone, but at the same time buried

84 Florido et al. 2011. 


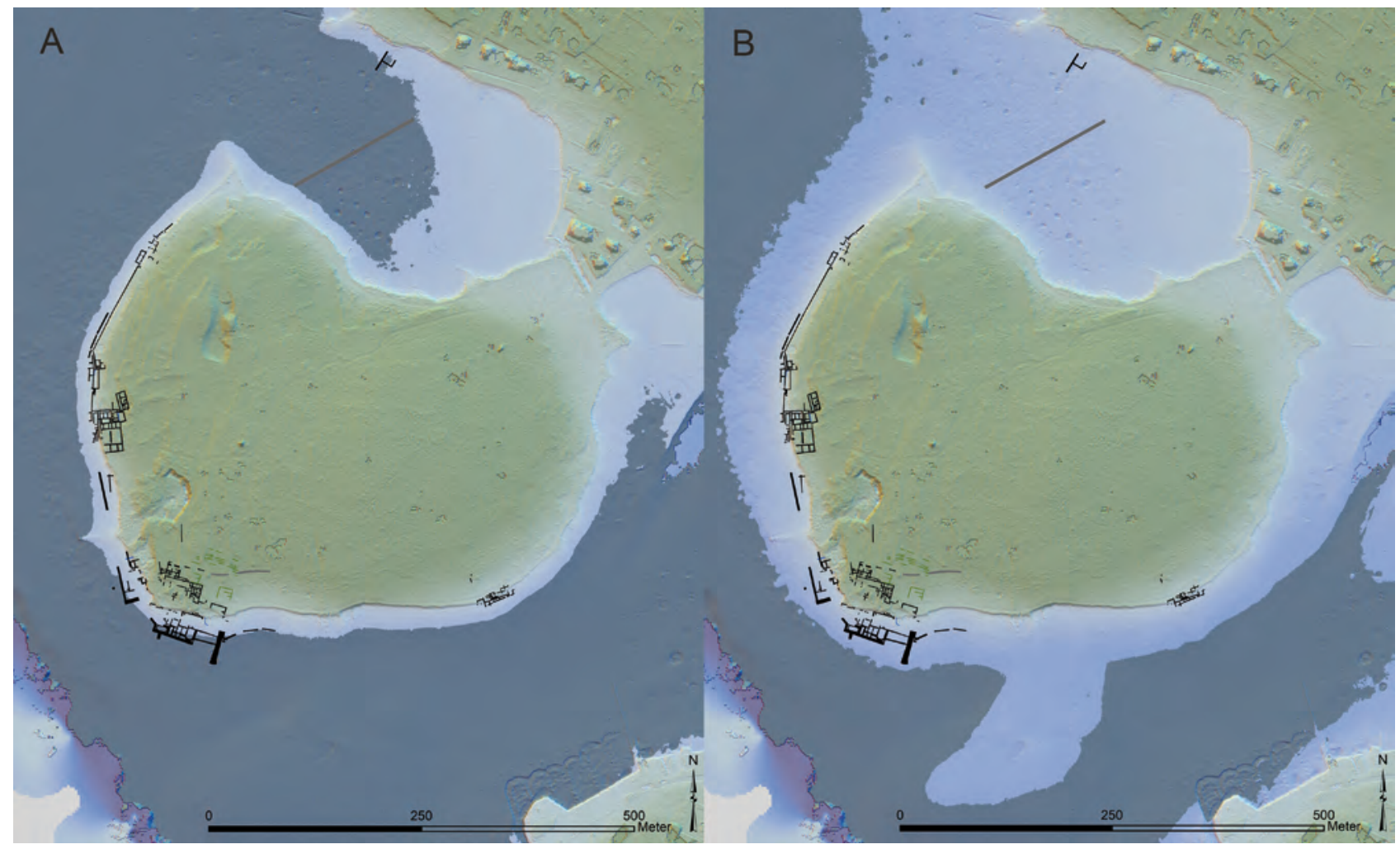

Fig. 25. Different visualizations of the coastal area based on modelling a lower sea level at $-1.5 \mathrm{~m}(\mathrm{~A})$ and $-3 \mathrm{~m}(\mathrm{~B})$ based on ALS/ALB data (Graphic: N. Doneus).

submerged parts under a thick layer of deposited sediments. Marijan Orlici ${ }^{85}$ mentions that underwater sediments containing archaeological finds are up to $2 \mathrm{~m}$ thick and, based on experience from underwater excavations, it is shown that within less than a year up to $5 \mathrm{~cm}$ of sediment can be deposited in the shallow sea. For this reason, a GIS modelled effect of a changing sea level based on ALS/ABT data can provide only limited information about the actual underwater topography during Roman times. This is shown very clearly in Figure 25/A where the sea level is lowered by $1.5 \mathrm{~m}$. The indication, that today's underwater topography does not correspond with the relief during Roman times is visible especially in the course of the Roman road, which, according to ALS/ALB, is situated in the sea. Such visualizations should therefore only be understood as a tool for improved presentation and are - without further geoarchaeological data - not suitable for reconstruction of the sea level changes on a local scale.

Despite all these limitations, some conclusions can be drawn about the topographic changes on Vižula. The current dimensions of the peninsula are about $200-500 \mathrm{~m}$ by

85 OrLić 1995, 67.
$600 \mathrm{~m}$ (about $24 \mathrm{ha}$ ). Today's narrow land bridge, which is surrounded to the east and west by shallow, muddy water, was probably as wide as the peninsula itself during Roman times. Evidence for this assumption can be found in the position and course of the Roman road, which today has become completely submerged. Also, the villa of Nježin vrt, ${ }^{86}$ which is the nearest known neighbour in the north of Vižula, is partly submerged today (Fig. 23). The oldest burials from the Burle cemetery from the SW part of the necropolis (Fig. 4) also lie below today's sea level. ${ }^{87}$

South of Vižula, the coastline towards Medulin Bay was also different. This is relevant both for interpretation of the building complexes, and for the Roman shipping. Today, the peninsula of Vižula does not offer a safe anchorage. The $\mathrm{S}$ and SE winds make anchoring impossible during stormy weather. In Roman times, however, an anchorage was available, made possible by an underwater land elevation (Fig. 25/B). This elevation-regardless of whether it reached above the sea level or not-served as a natural breakwater and

86 In the beach area and the shallow water several stone walls are visible, accompanied by small Roman finds.

87 DžIN 2008, 16. 
made it possible to dock at the Roman pier (Object F). This underwater elevation also explains why the pier was built at this very spot. Nevertheless, it does not seem appropriate to speak of a Roman harbour, as protection is inadequate and the available space for ships is limited. In this sense, it would be better to interpret the pier as a landing point that allowed direct access to the villa from the sea. Whether the sea water was actually as shallow as Mario Juriši ic ${ }^{88}$ suggested, allowing only a 'small' coastal navigation and boats with a depth of max. $1 \mathrm{~m}$ (about $10 \mathrm{~m}$ length), cannot be verified at the present.

\section{Conclusion}

The Roman heritage of Vižula is unique among archaeological sites in Istria as an unusually high number of architectural remains are not just preserved but also accessible for modern research. The extension of the Roman architecture to more than $1 \mathrm{~km}$ in length makes it difficult for archaeologists to consider every aspect of the site. Furthermore, the remains themselves are difficult to interpret, as Xavier Lafon pointed out in 2009: "Are we dealing with a whole or a part, knowing that the same elements can occur in complexes of a very different nature..." ${ }^{89}$ In Vižula's case, this is particularly true of the submerged architecture, which presents itself 'naked', without any decoration or other indication of function. In addition, it should also be remembered that each villa maritima has its own character. Building layouts may follow generally accepted rules of fashion, functionality or the predominant construction technique, and yet each of these luxurious properties is unique. This makes it extremely difficult to classify them on the basis of floor plans alone.

But it is not only the size or the state of preservation of archaeological features that makes the documentation and interpretation of Vižula difficult; single archaeological methods also reached their limits here. Due to the size of the site, archaeological excavations have limited potential to advance research at an affordable tempo. Archaeological prospection, as efficient as it may be compared to the excavations, was not always successful due to prevailing landscape conditions (dense vegetation and terrestrial/underwater soil conditions).

Nevertheless, the experience from Vižula shows that it is always beneficial for research when different field methods

88 JURIšić 2006, 310.

89 LAFON 2009, 164: “A-t-on affaire à un ensemble ou à une partie, sachant que les mêmes éléments peuvent prendre place dans des complexes de nature très différente...”. are combined. Without the combination of the underwater and terrestrial research, integrated prospection and the consideration of the topography in the two different habitats, it would not have been possible to decode the architecture of Vižula.

\section{Acknowledgements}

We would like to thank the Municipality of Medulin for its commitment to supporting archaeological prospection and good cooperation during the project "Archaeological Park Vižula" (2017-2019).

Archaeological prospection always requires support on the site. Here we would like to thank the members of the terrestrial (Klaudija Bartolić Sirotić, Davor Bulić, Zrinka Ettinger Starčić, Ivan Okmaca, Aleksandra Paić, Monika Petrović, Marko Uhač and Elvin Zejnilhodžić) and underwater (Jerko Macura, Ana Skračić, Iva Stojević, Goran Trninić, Kristina Vodička Miholjek and Vesna Zmaić Kralj) teams. Geophysical prospection was conducted by the LBI ArchPro team including, alongside Nives Doneus and Hannes Schiel, also Manuel Gabler, Viktor Jansa and Matthias Kucera.

In the evaluation of prospection data we have received support from several different specialists. We would like to thank Gottfried Mandlburger, Technical University Vienna, for his assistance in the data processing. Also Andrej Bader, the local historian from Medulin, should be thanked for sharing his knowledge about the history of the region with us. Thanks also go to Helga Sedlmayer, Austrian Archaeological Institute, for the discussion on Roman architecture.

The Ludwig Boltzmann Institute for Archaeological Prospection and Virtual Archaeology (archpro.lbg.ac.at) is based on an international cooperation of the Ludwig Boltzmann Gesellschaft (A), Amt der Niederösterreichischen Landesregierung (A), University of Vienna (A), TU Wien (A), ZAMG - Central Institute for Meteorology and Geodynamics (A), 7reasons (A), ArcTron 3D (D), LWL - Federal state archaeology of Westphalia-Lippe (D), NIKU - Norwegian Institute for Cultural Heritage $(\mathrm{N})$ and Vestfold fylkeskommune-Kulturarv (N).

\section{References}

Antonioli et al. 2007

F. Antonioli, M. Anzidei, K. Lambeck, R. Auriemma, D. GadDi, S. Furlani, P. Orrù, E. Solinas, A. Gaspari, S. Karinja, V. Kovačić, L. Surace, Sea-level change during the Holocene in Sardinia and in the northeastern Adriatic (central Mediterranean Sea) from archaeological and geomorphological data, Quaternary Science Reviews 26, 2007, 2463-2486. doi: 10.1016/j.quascirev.2007.06.022.

BAČIĆ 1969

B. BAčıć, Medulin, Ižula, Istra - neolitsko naselje, Arheološki pregled 11, 1969, 23-24.

BADER 2013

A. BADER, Hrvatski Sokol Medulin. In: Monografija općine Medulin. Medulin 2013, 196-209.

BADER 2016

A. BADER, Iz fotoalbuma Richarda Schustera, 1914-1917 / Aus dem Fotoalbum von Richard Schuster, 1914-1917. Pula 2016.

Begović Dvoržak, Dvoržak Schrunk 2004

V. Begović DvoržAK, I. DvoržAk Schrunk, Roman villas in Istria and Dalmatia, part III: maritime villas / Rimske vile u Istri i Dalmaciji III - Maritimne vile, Prilozi Instituta za arheologiju u Zagrebu 21, 2004, 65-90. 
BENNETT et al. 2012

R. Bennett, K. Welham, R. A. Hill, A. Ford, A comparison of visualization techniques for models created from airborne laser scanned data, Archaeological Prospection 19, 2012, 41-48. doi: 10.1002/arp.1414.

BERTOŠA 2013

M. BertošA, Stoljeća Medulina. In: Monografija općine Medulin. Medulin 2013, 92-115.

Bevan, Smekalova 2013

B. V. Bevan, T. N. Smekalova, Magnetic exploration of archaeological sites. In: C. Corsi, B. Slapšak, F. Vermeulen (Eds.), Good Practice in Archaeological Diagnostics: Non-Invasive Survey of Complex Archaeological Sites. Natural Science in Archaeology, Cham - Heidelberg - New York - Dordrecht - London 2013, $133-152$.

BLOIER 2013

M. Bloier, Die taucharchäologischen Untersuchungen in der Val Catena-Bucht auf Brioni (Istrien/Kroatien) 1996/97: Befunde und Funde. Passauer Universitätsschriften zur Archäologie 14, Rahden/Westfalen 2013.

BoIsSINOT 1995

P. Воissinot, L'empreinte des paysages hellénistiques dans les formations holocènes de Saint-Jean du Désert (Marseille). In: C. Morhange (Ed.), Les origines de Marseille: Environnement et archéologie. Méditerranée 82/3-4, Aix-en-Provence 1995, 33-40. doi: 10.3406/medit.1995.2899.

Boissinot, Puig 1995

P. Boissinot C. Puig, Archéologie du champ et viticulture méridionale: Pourquoi les traces de vignobles sont-elles si peu fréquentes au Moyen Age? Archéologie du Midi medieval 23-24, 2005, 17-26. doi: 10.3406/amime.2005.1820.

BOWDEN 2018

W. BOWDEN, Villas of the eastern Adriatic and Ionian coastlands. In: A. Marzano, G. P. R. MÉtraux (Eds.), The Roman Villa in the Mediterranean Basin: Late Republic to Late Antiquity. Cambridge 2018, 377-397.

Brown et al. 2001

A. G. Brown, I. Meadows, S. D. Turner, D. J. Mattingly, Roman vineyards in Britain: stratigraphic and palynological data from Wollaston in the Nene Valley, England, Antiquity 75, 2001, 745-757. doi: 10.1017/S0003598X00089250.

Challis, Forlin, Kincey 2011

K. Challis, P. Forlin, M. Kincey, A generic toolkit for the visualization of archaeological features on airborne LiDAR elevation data, Archaeological Prospection 18, 2011, 279-289. doi: 10.1002/arp.421.

CoDACCi 2004

G. CoDAcci, Il sito neolitico di Vižula: analisi tipologica dell'industria litica, Histria Archaeologica 33, 2004, 143-193.

Cozzolino et al. 2018

M. Cozzolino, E. Di Giovanni, P. Mauriello, S. Piro, D. ZAMUNER(Eds.), Geophysical Methods for Cultural Heritage Management. Springer Geophysics, Cham - Heidelberg - New York - Dordrecht - London 2018.

Crnković 1991

B. CRnković, Porijeklo kamena Arene u Puli, Rudarsko-geološko-naftni zbornik 3/1, 1991, 63-67.

Crutchley 2010

S. Crutchley, The Light Fantastic: Using Airborne Lidar in Archaeological Survey. Swindon 2010.
D’Arms 1970

J. H. D'Arms, Romans on the Bay of Naples: A Social and Cultural Study of the Villas and their Owners from 150 B.C. to A.D. 400. Loeb Classical Monographs, Cambridge, Mass. 1970.

Doneus 2013

M. Doneus, Openness as visualization technique for interpretative mapping of airborne lidar derived digital terrain models, Remote Sensing of Environment 5, 2013, 6427-6442. doi: 10.3390/ rs5126427.

Doneus, Briese 2011

M. Doneus, C. Briese, Airborne laser scanning in forested areas potential and limitations of an archaeological prospection technique. In: D. Cowley (Ed.), Remote Sensing for Archaeological Heritage Management. Occasional Publication of the Aerial Archaeology Research Group 3, Budapest 2011, 53-76.

Doneus, Doneus, EtTinger-STARČić 2017

N. Doneus, M. Doneus, Z. EtTinger-Starčić, The ancient city of Osor, northern Adriatic, in integrated archaeological prospection, Hortus artium medievalium 23/2, 2017, 761-775. doi: 10.1484/J.HAM.5.113761.

Doneus, Mandlburger, Doneus 2020

M. Doneus, G. Mandlburger, N. Doneus, Archaeological filtering of airborne laser scan derived point-clouds in difficult environments, Journal of Computer Applications in Archaeology 3/1, 2020, 92-108. doi: 10.5334/jcaa.44.

Doneus et al. 2013

M. Doneus, N. Doneus, C. Briese, M. Pregesbauer, G. Mandlburger, G. Verhoeven, Airborne laser bathymetry - detecting and recording submerged archaeological sites from the air, Journal of Archaeological Science 4, 2013, 2136-2151. doi: 10.1016/j. jas.2012.12.021.

Doneus et al. 2015

M. Doneus, I. Miholjek, G. Mandlburger, N. Doneus, G. Verhoeven, C. Briese, M. Pregesbauer, Airborne laser bathymetry for documentation of submerged archaeological sites in shallow water. In: F. Menna, E. Nocerino, S. Del Pizzo, F. Bruno, F. Remondino (Eds.), Underwater 3D Recording and Modelling. ISPRS The International Archives of the Photogrammetry, Remote Sensing and Spatial Information Sciences 40-5/W5, Piano di Sorrento 2015, 99-107. doi: 10.5194/isprsarchives-XL-5-W5-99-2015.

Doneus et al. 2018

N. Doneus, W. Neubauer, M. Doneus, M. Wallner, Die archäologische Landschaft von Halbturn: Ergebnisse aus drei Jahrzehnten integrierter archäologischer Prospektion, Archaeologia Austriaca 102, 2018, 201-226. doi: 10.1553/archaeologia102s201.

DURN 2003

G. Durn, Terra Rossa in the Mediterranean region: parent materials, composition and origin, Geologia Croatica 56/1, 2003, 83-100. doi: 10.4154/GC.2003.06.

DŽIN 1995

K. DžIN, Spomenički nalazi i projekat eko-arheološkog parka Vižula kod Medulina, Histria Antiqua 1, 1995, 73-78.

DžIN 2008

K. Džın, Antička i kasnoantička nekropola Burle u Medulinu / Antique and late antique necropolis of Burle in Medulin. In: K. Džın, V. Giradi Jurkić (Eds.), Vižula i Burle u antici / Vižula and Burle in Roman Period. Arheološki muzej Istre, Katalog 76, Pula 2008, 16-21. 
DŽIN 2013

K. Džın, Antička kulturna baština općine Medulin. In: Monografija općine Medulin. Medulin 2013, 64-77.

FAIVRE et al. 2010

S. Faivre, E. Fouache, V. Kovačić, S. Glušćević, Geomorphological and archaeological indicators of Croatian shoreline evolution over the last two thousand years, GeoActa, Special Publication 3, 2010, 125-133.

FARRAR 2000

L. Farrar, Ancient Roman Gardens, $2^{\text {nd }}$ edition. Stroud, Gloucestershire 2000.

FERNANDEZ-Diaz et al. 2014

J. Fernandez-Diaz, W. Carter, R. Shrestha, C. Glennie, Now you see it... now you don't: understanding airborne mapping LiDAR collection and data product generation for archaeological research in Mesoamerica, Remote Sensing 6/10, 2014, 995110001. doi: 10.3390/rs6109951.

FLORIDO et al. 2011

E. Florido, R. Auriemma, S. Faivre, I. Radić Rossi, F. AntoNIOLI, S. Furlani, G. SPAda, Istrian and Dalmatian fishtanks as sea-level markers, Quaternary International 232, 2011, 105-113. doi: 10.1016/j.quaint.2010.09.004.

FONTANA 1993

F. FonTANA, La villa romana di Barcola: A proposito delle villae maritimae della Regio X. Studi e ricerche sulla Gallia Cisalpina 4, Rome 1993.

Giradi JuRKIĆ 2008a

V. Giradi Jurkić, Rezidencijska antička vila na Vižuli / Antique residential villa at Vižula. In: K. DžIn, V. Giradi Jurkić (Eds.), Vižula i Burle u antici / Vižula and Burle in Roman Period. Arheološki muzej Istre, Katalog 76, Pula 2008, 5-15.

GIRARDi JuRKIĆ 2008b

V. GIRARDI JURKIĆ, Late antique hearts in the Roman residential villa on the Vižula peninsula near Medulin, campaign 2007, Histria Antiqua 16, 2008, 161-168.

GirARDi-JuRKić 2013

V. Girardi-Jurkić, Povijesni i gospodarski razvitak južne Istre u antici. In: Monografija općine Medulin. Medulin 2013, 44-63.

GirARdi JURKIĆ et al. 2012

V. Girardi Jurkić, K. Džin, A. Paić, Z. EtTinger Starčić, Vižula kod Medulina: Rezidencijska maritimna vila: istraživačka kampanja 2011, Histria Antiqua 21, 2012, 509-523.

GNIRS 1908

A. GNIRs, Istrische Beispiele für Formen der antik-römischen villa rustica, Jahrbuch für Altertumskunde 2, 1908, 124-143.

GNIRS 1910

A. GNIRs, Istrische Forschungsergebnisse auf dem Gebiete des römischen Villenbaus. In: Verhandlungen der fünfzigsten Versammlung deutscher Philologen und Schulmänner. Leipzig 1910, 121-123.

GNIRS 1915

A. GNIRs, Forschungen über antiken Villenbau in Südistrien, Jahreshefte des Österreichischen Archäologischen Institutes in Wien 18, 1915, 99-164.

Gobić Bravar 2006

Đ. Gobić Bravar, Antički mramori s arheološkog lokaliteta Vižula kod Medulina, Histria Antiqua 14, 2006, 315-321.

Groh, Sedlmayer 2017

S. Groh, H. Sedlmayer, Otium cum dignitate et negotium trans mare: La villa marittima di San Simone (Simonov zaliv) in Istria (Slovenia). Ricerche, Series maior 7, Bologna 2017.
GruSSENMEYER et al. 2016

P. Grussenmeyer, T. Landes, M. Doneus, J. L. Lerma, Basics of range-based modelling techniques in cultural heritage $3 \mathrm{D}$ recording. In: E. Stylianidis, F. Remondino (Eds.), 3D Recording, Documentation and Management of Cultural Heritage. Caithness 2016, 305-364.

GuALTIERI 2018

M. Gualtieri, Roman villas in southern Italy. In: A. Marzano, G. P. R. MÉtraux (Eds.), The Roman Villa in the Mediterranean Basin: Late Republic to Late Antiquity. Cambridge 2018, 159-176.

Hesse 2010

R. Hesse, LiDAR-derived local relief models - a new tool for archaeological prospection, Archaeological Prospection 17/2, 2010, 67-72. doi: 10.1002/arp.374.

JURIŠIĆ 1997

M. Jurišıć, Antički ribnjak u uvali Verige na Brijunima. In: Arheološka istraživanja u Istri, Znanstveni skup Poreč, 22-26. IX. 1994. Izdanja Hrvatskog arheološkog društva 18, Zagreb 1997, 163-168.

JURIŠIĆ 2006

M. JuRIŠı́́, Podmorska arheološka istraživanja na Vižuli - pokretni nalazi, Histria Antiqua 14, 2006, 303-313.

KOKALJ, SOMRAK 2019

Ž. KoKalJ, M. Somrak, Why not a single image? Combining visualizations to facilitate fieldwork and on-screen mapping, Remote Sensing 11/7, 2019, 747. doi: 10.3390/rs11070747.

KOKALJ, ZaKŠEK, OšTiR 2011

Ž. KokalJ, K. ZaKšEK, K. OšTir, Application of sky-view factor for the visualisation of historic landscape features in lidar-derived relief models, Antiquity 85, 2011, 263-273. doi: 10.1017/ S0003598X00067594.

KOKALJ, ZAKŠEK, OŠTiR 2013

Ž. KoKALJ, K. ZAKŠEK, K. OšTiR, Visualizations of Lidar derived relief models. In: R. S. OpITZ, D. C. Cowley (Eds.), Interpreting Archaeological Topography: Airborne Laser Scanning, 3D Data and Ground Observation. Occasional Publication of the Aerial Archaeology Research Group 5, Oxford 2013, 100-114.

KONCANi UHAČ 2018

I. Koncani Uhač, Rimski lučki uređaji u Istri i njihov arheološki kontekst. Dissertation, University of Zadar 2018.

Kozličić 1986

M. Kozličıć, Antička obalna linija Istre u svijetlu hidroarheoloških istraživanja, Izdanja Hrvatskog arheološkog društva 11/2, 1986, 135-165.

LAFON 2001

X. LAFON, Villa maritima: Recherches sur les villas littorales de l'Italie romaine ( $\mathrm{III}^{\mathrm{e}}$ siècle av. J.-C./III ${ }^{\mathrm{e}}$ siècle ap. J.-C.). Bibliothèque des Écoles Françaises d'Athènes et de Rome 307, Rome 2001.

\section{LAFON 2009}

X. LAFOn, Les villas maritimes construites sur le littoral méditerranéen français: essai de bilan. In: X. Delestre, H. Marchesi (Eds.), Archéologie des rivages méditerranéens: 50 ans de recherche. Actes du colloque d'Arles (Bouches-du-Rhône), 28-30 octobre 2009. Arles 2009, 163-171.

Marzano, Métraux 2018

A. Marzano, G. P. R. Métraux, The Roman villa: an overview. In: A. Marzano, G. P. R. Métraux (Eds.), The Roman Villa in the Mediterranean Basin: Late Republic to Late Antiquity. Cambridge 2018, 1-41. 
Matijašić 1998

R. MatijašIć, Gospodarstvo antičke Istre: Arheološki ostaci kao izvori za poznavanje društveno-gospodarskih odnosa u Istri u antici (I. st. pr. Kr. - III st. posl. Kr.). Pula 1998.

MATiJašić 2012

R. MATIJAšıć, Još jedan primjer fosiliziranoga antičkog krajolika u Istri: Rt Kamenjak (Premantura, Pula), Tabula - časopis Filozofskog fakulteta 10, 2012, 75-89.

Menna, Agrafiotis, Georgopoulos 2018

F. Menna, P. Agrafiotis, A. Georgopoulos, State of the art and applications in archaeological underwater 3D recording and mapping, Journal of Cultural Heritage 33, 2018, 231-248. doi: 10.1016/j.culher.2018.02.017.

MiHOLJEK 2006

I. Miнoljek, Podmorsko arheološko istraživanje ostataka arhitekture poluotoka Vižule kod Medulina, Histria Antiqua 14, 2006, 293-301.

Miноцjeк 2012

I. Miноцjeк, Podmorsko istraživanje antičkih ostataka arhitekture na Vižuli - kampanja 2011, Histria Antiqua 21, 2012, 525-531.

Neubauer et al. 2012

W. Neubauer, M. Doneus, I. Trinks, G. Verhoeven, A. HinterLEITNER, S. SEREN, K. LÖCKER, Long-term integrated archaeological prospection at the Roman town of Carnuntum/Austria. In: P. Johnson, M. Millett (Eds.), Archaeological Survey and the City. University of Cambridge Museum of Classical Archaeology Monograph 2, Oxford 2012, 202-221.

Novo 2013

A. Novo, Ground-penetrating radar (GPR). In: C. CoRsI, B. Slapšak, F. Vermeulen (Eds.), Good Practice in Archaeological Diagnostics: Non-invasive Survey of Complex Archaeological Sites. Natural Science in Archaeology, Cham - Heidelberg - New York - Dordrecht - London 2013, 165-176.

Opitz, Cowley 2013

R. S. OpITZ, D. C. CowLEY, Interpreting archaeological topography: lasers, 3D data, observation, visualisation and applications. In: R. S. Opitz, D. C. Cowley (Eds.), Interpreting Archaeological Topography: Airborne Laser Scanning, 3D Data and Ground Observation. Occasional Publication of the Aerial Archaeology Research Group 5, Oxford 2013, 1-12.

ORLIĆ 1995

M. ORLIĆ, Podmorsko arheološko istraživanje dijela arheološkog kompleksa Vižula kod Medulina, Histria Antiqua 1, 1995, 64-72.

PARICA 2012

M. PARICA, Nekoliko primjera lučkih instalacija antičkih kamenoloma na dalmatinskim otocima, Histria Antiqua 21, 2012, 345-354.

Percan 2013

A. Percan, Naselja općine Medulin u svjetlu katastra iz 19. stoljeća. In: Monografija općine Medulin. Medulin 2013, 156-168.

Pflederer 2014

T. Pflederer, Rimski mol 1 u Veštru: Arheološki nalazi i usporedba s drugim pristaništima rimskog doba u Istri / Die römische Hafenmole 1 von Veštar: Archäologischer Befund und Vergleich mit weiteren römerzeitlichen Schiffsanlegestellen in Istrien. In: L. Bекіć (Ed.), Luka Veštar: Podvodno arheološko istraživanje u uvali Veštar kod Rovinja, Hrvatska, 2008-2014 / Der Hafen von Veštar: Unterwasserarchäologische Untersuchung in der Bucht von Veštar bei Rovinj, Kroatien, 2008-2014. Istraživačke studije iz podvodne arheologije 1, Zadar 2014, 43-50.

\section{Pohlsander 1984}

H. A. Pohlsander, Crispus: brilliant career and tragic end, Historia - Zeitschrift für Alte Geschichte 33/1, 1984, 79-106.

SchмidT et al. 2015

A. R. Schmidt, P. Linford, N. Linford, A. David, C. F. Gaffney, A. SARris, J. Fassbinder (Eds.), EAC Guidelines for the Use of Geophysics in Archaeology: Questions to Ask and Points to Consider: EAC Guidelines 2. Namur 2015.

SCHUCANY 2011

C. Schucany, The villa landscape of the Middle Aare valley and its spatial and chronological development. In: N. Roymans, T. Derks (Eds.), Villa Landscapes in the Roman North: Economy, Culture and Lifestyles. Amsterdam Archaeological Studies 17, Amsterdam 2011, 275-283.

Teichner, Ugarković 2012

F. Teichner, M. Ugarković, Zeugnisse einer römischen villa maritima auf der Insel des Heiligen Clemens, Dalmatien, Germania 90, 2012, 97-125.

Trinks et al. 2018

I. Trinks, A. Hinterleitner, W. Neubauer, E. Nau, K. Löck-

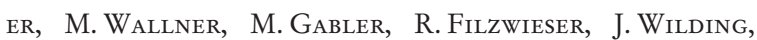
H. Schiel, V. Jansa, P. Schneidhofer, T. Trausmuth, V. SAndici, D. Russ, S. Flöry, J. Kainz, M. Kucera, A. Vonkilch，T. Tencer， L. Gustavsen， M. Kristiansen, L.- M. Bye-Johansen， C. Tonning， T.Zitz， K. PaAsche, T. GANSUM, S. SEREN, Large-area high-resolution ground-penetrating radar measurements for archaeological prospection, Archaeological Prospection 25/3, 2018, 171-195. doi: 10.1002/ arp.1599.

VACCHI et al. 2016

M. Vacchi, N. Marriner, C. Morhange, G. Spada, A. FontANA, A. Rovere, Multiproxy assessment of Holocene relative sea-level changes in the western Mediterranean: sea-level variability and improvements in the definition of the isostatic signal, Earth-Science Reviews 155, 2016, 172-197. doi: 10.1016/j.earscirev.2016.02.002.

VOLPE 2009

R. Volpe, Vini, vigneti ed anfore in Roma repubblicana. In: V. JolIvet, C. Pavolini, M. A. Tomei, R. Volpe (Eds.), Suburbium II: Il suburbio di Roma dalla fine dell'età monarchica alla nascita del sistema delle ville (V-II secolo A.C.). Atti delle Giornate di Studio sul Suburbio Romano tenute a Roma il 16 ottobre e 3 novembre 2004, 17 e 18 febbraio 2005. Collection de l'École Française de Rome 419, Rome 2009, 369-392.

Nives Doneus

Austrian Archaeological Institute Austrian Academy of Sciences Franz Klein-Gasse 1

1190 Vienna

Austria

n.doneus@gmail.com

orcid.org/0000-0002-9336-4254 
Igor Miboljek

Croatian Conservation Institute Department for Underwater Archaeology

Cvijete Zuzorić 43 10000 Zagreb

Croatia

imiboljek@brz.hr

orcid.org/0000-0002-0095-0642

Kristina Džin Institut društvenih znanosti Ivo Pilar Marulićev trg 19/1 10000 Zagreb

Croatia

kristina.dzin@pu.htnet.hr orcid.org/0000-0002-6116-2359

Michael Doneus

Institute for Prebistoric and Historical Archaeology University of Vienna Franz-Klein-Gasse 1 1190 Vienna Austria michael.doneus@univie.ac.at orcid.org/0000-0001-5091-0094

Pavle Dugonjić Croatian Conservation Institute Department for Underwater Archaeology

Cvijete Zuzorić 43 10000 Zagreb Croatia pdugonjic@brz.hr orcid.org/0000-0001-7864-682X

Hannes Schiel Ludwig Boltzmann Institute for Archaeological Prospection and Virtual Archaeology

Hobe Warte 38 1190 Vienna Austria bannes.schiel@archpro.lbg.ac.at orcid.org/0000-0002-9128-4883 